\title{
Daytime formation of nitrous acid at a coastal remote site in Cyprus indicating a common ground source of atmospheric HONO and NO
}

\author{
Hannah Meusel ${ }^{1}$, Uwe Kuhn ${ }^{1}$, Andreas Reiffs ${ }^{2}$, Chinmay Mallik ${ }^{2}$, Hartwig Harder ${ }^{2}$, Monica Martinez ${ }^{2}$, \\ Jan Schuladen ${ }^{2}$, Birger Bohn ${ }^{3}$, Uwe Parchatka ${ }^{2}$, John N. Crowley ${ }^{2}$, Horst Fischer ${ }^{2}$, Laura Tomsche ${ }^{2}$, Anna Novelli ${ }^{2,3}$, \\ Thorsten Hoffmann ${ }^{4}$, Ruud H. H. Janssen ${ }^{2}$, Oscar Hartogensis ${ }^{5}$, Michael Pikridas ${ }^{6}$, Mihalis Vrekoussis ${ }^{6,7,8}$, \\ Efstratios Bourtsoukidis $^{2}$, Bettina Weber ${ }^{1}$, Jos Lelieveld ${ }^{2}$, Jonathan Williams ${ }^{2}$, Ulrich Pöschl ${ }^{1}$, Yafang Cheng ${ }^{1}$, and \\ Hang $\mathrm{Su}^{1}$ \\ ${ }^{1}$ Max Planck Institute for Chemistry, Multiphase Chemistry Department, Mainz, Germany \\ ${ }^{2}$ Max Planck Institute for Chemistry, Atmospheric Chemistry Department, Mainz, Germany \\ ${ }^{3}$ Institute for Energy and Climate Research (IEK-8), Research Center Jülich, Jülich, Germany \\ ${ }^{4}$ Johannes Gutenberg University, Inorganic and Analytical Chemistry, Mainz, Germany \\ ${ }^{5}$ Wageningen University and Research Center, Meteorology and Air Quality, Wageningen, the Netherlands \\ ${ }^{6}$ Cyprus Institute, Energy, Environment and Water Research Center, Nicosia, Cyprus \\ ${ }^{7}$ Institute of Environmental Physics and Remote Sensing - IUP, University of Bremen, Bremen, Germany \\ ${ }^{8}$ Center of Marine Environmental Sciences - MARUM, University of Bremen, Bremen, Germany
}

Correspondence to: Hang Su (h.su@mpic.de)

Received: 24 June 2016 - Published in Atmos. Chem. Phys. Discuss.: 25 July 2016

Revised: 27 October 2016 - Accepted: 5 November 2016 - Published: 22 November 2016

\begin{abstract}
Characterization of daytime sources of nitrous acid (HONO) is crucial to understand atmospheric oxidation and radical cycling in the planetary boundary layer. HONO and numerous other atmospheric trace constituents were measured on the Mediterranean island of Cyprus during the CYPHEX (CYprus PHotochemical EXperiment) campaign in summer 2014. Average volume mixing ratios of $\mathrm{HONO}$ were $35 \mathrm{pptv}( \pm 25 \mathrm{pptv})$ with a $\mathrm{HONO} / \mathrm{NO}_{x}$ ratio of 0.33 , which was considerably higher than reported for most other rural and urban regions. Diel profiles of HONO showed peak values in the late morning $(60 \pm 28 \mathrm{pptv}$ around 09:00 local time) and persistently high mixing ratios during daytime ( $45 \pm 18 \mathrm{pptv}$ ), indicating that the photolytic loss of HONO is compensated by a strong daytime source. Budget analyses revealed unidentified sources producing up to $3.4 \times 10^{6}$ molecules $\mathrm{cm}^{-3} \mathrm{~s}^{-1}$ of HONO and up to $2.0 \times 10^{7}$ molecules $\mathrm{cm}^{-3} \mathrm{~s}^{-1} \mathrm{NO}$. Under humid conditions (relative humidity $>70 \%$ ), the source strengths of HONO and NO exhibited a close linear correlation $\left(R^{2}=\right.$ 0.72 ), suggesting a common source that may be attributable to emissions from microbial communities on soil surfaces.
\end{abstract}

\section{Introduction}

Nitrous acid (HONO) is an important component of the nitrogen cycle, being widespread in the environment. Either in its protonated form ( $\mathrm{HONO}$ or $\left.\mathrm{HNO}_{2}\right)$ or as nitrite ions $\left(\mathrm{NO}_{2}^{-}\right)$ it can be found not only in the gas phase, on aerosol particles, in clouds and in dew droplets but also in soil, seawater and sediments (Foster et al., 1990; Rubio et al., 2002; Acker et al., 2005, 2008; Bianchi et al., 1997). It plays a key role in the oxidizing capacity of the atmosphere, as it is an important precursor of the $\mathrm{OH}$ radical, which initiates most atmospheric oxidations. $\mathrm{OH}$ radicals react with pollutants in the atmosphere to form mostly less toxic compounds (e.g. $\mathrm{CO}+\mathrm{OH} \rightarrow \mathrm{CO}_{2}+\mathrm{H}_{2} \mathrm{O}$; Levy, 1971). Volatile organic compounds (VOCs) react with $\mathrm{OH}$, contributing to formation of secondary aerosols (SOAs), which can serve as cloud condensation nuclei (CCN; Arey et al., 1990; Duplissy et al., 2008). Furthermore $\mathrm{OH}$ oxidizes $\mathrm{SO}_{2}$ to $\mathrm{H}_{2} \mathrm{SO}_{4}$, which condense subsequently to form aerosol particles (Zhou et al., 2013). In this way HONO has an indirect effect on the radiative budget and climate. In the first $2-3 \mathrm{~h}$ following sunrise, when $\mathrm{OH}$ production from other sources (photolysis of $\mathrm{O}_{3}$ 
and formaldehyde) is relatively low, photolysis of HONO can be the major source of $\mathrm{OH}$ radicals as HONO concentrations may be high after accumulation during nighttime (Lammel and Cape, 1996; Czader et al., 2012; Mao et al., 2010). On average up to $30 \%$ of the daily $\mathrm{OH}$ budget in the boundary layer is provided by HONO photolysis (Alicke et al., 2002; Kleffmann et al., 2005; Ren et al., 2006), but it has been reported as high as $56 \%$ (Ren et al., 2003), with ambient HONO mixing ratios ranging from several parts per trillion by volume (pptv) in rural areas up to a few parts per billion by volume (ppbv) in highly polluted regions (Acker et al., 2006a, b; Costabile et al., 2010; Li et al., 2012; Michoud et al., 2014; Spataro et al., 2013; Su et al., 2008a; Zhou et al., 2002a).

In early studies, atmospheric HONO was assumed to be in a photostationary state (PSS) during daytime controlled by the gas-phase reaction of $\mathrm{NO}$ and $\mathrm{OH}$ (Reaction R1) and two loss reactions, which are the photolysis (Reaction R2) and the reaction with $\mathrm{OH}$ (Reaction $\mathrm{R} 3$ ).

$\mathrm{OH}+\mathrm{NO} \rightarrow \mathrm{HONO}$

$\mathrm{HONO} \stackrel{h v(300-405 \mathrm{~nm})}{\longrightarrow} \mathrm{OH}+\mathrm{NO}$

$\mathrm{HONO}+\mathrm{OH} \rightarrow \mathrm{NO}_{2}+\mathrm{H}_{2} \mathrm{O}$

However, field measurements in remote and rural locations as well as urban and polluted regions found severaltimes-higher daytime HONO concentrations than model predictions, suggesting a large unknown source (Kleffmann et al., 2003, 2005; Su et al., 2008a, 2011; Sörgel et al., 2011a; Michoud et al., 2014; Czader et al., 2012; Wong et al., 2013; Tang et al., 2015; Oswald et al., 2015) even after considering direct emission of HONO from combustion sources (Kessler and Platt, 1984; Kurtenbach et al., 2001). Heterogeneous reactions on aerosols have been proposed as an explanation for the missing source. The hydrolysis (Reaction R4; FinlaysonPitts et al., 2003) and redox reactions of $\mathrm{NO}_{2}$ have been intensively investigated on different kinds of surfaces such as fresh soot, aged particles or organic-coated particles (Ammann et al., 1998; Arens et al., 2001; Aubin and Abbatt, 2007; Bröske et al., 2003; Han et al., 2013; Kalberer et al., 1999; Kleffmann et al., 1999; Kleffmann and Wiesen, 2005; Lelievre et al., 2004). Minerals like $\mathrm{SiO}_{2}, \mathrm{CaCO}_{3}, \mathrm{CaO}$, $\mathrm{Al}_{2} \mathrm{O}_{3}$ and $\mathrm{Fe}_{2} \mathrm{O}_{3}$ showed a catalytic effect on the hydrolysis of $\mathrm{NO}_{2}$ (Kinugawa et al., 2011; Liu et al., 2015; Wang et al., 2003; Yabushita et al., 2009). Different kinds of surfaces (humic acid and other organic compounds, titanium dioxide, soot) can be photochemically activated, which leads to enhanced $\mathrm{NO}_{2}$ uptake and $\mathrm{HONO}$ production (Reaction R5, George et al., 2005; Langridge et al., 2009; Monge et al., 2010; Ndour et al., 2008; Ramazan et al., 2004; Stemmler et al., 2007; Kebede et al., 2013). The photolysis of particulate nitric acid $\left(\mathrm{HNO}_{3}\right)$, nitrate $\left(\mathrm{NO}_{3}^{-}\right)$and nitro-phenols $\left(\mathrm{R}-\mathrm{NO}_{2}\right.$ ) leads to HONO formation as well (Baergen and Donaldson, 2013; Bejan et al., 2006; Ramazan et al., 2004; Scharko et al., 2014; Zhou et al., 2003, 2011). But these re- actions cannot account for the HONO levels observed during daytime (Elshorbany et al., 2012).

$2 \mathrm{NO}_{2}+\mathrm{H}_{2} \mathrm{O} \rightarrow \mathrm{HONO}+\mathrm{HNO}_{3}$

surface $\stackrel{h v}{\longrightarrow} e^{-} \stackrel{\mathrm{NO}_{2}}{\longrightarrow} \mathrm{NO}_{2}^{-} \stackrel{\mathrm{H}_{2} \mathrm{O}}{\longrightarrow} \mathrm{HONO}+\mathrm{OH}^{-}$

On the other hand, soil nitrite, either biogenic or nonbiogenic, has been suggested as an effective source of HONO (Su et al., 2011; Oswald et al., 2013; Mamtimin et al., 2016). Depending on soil properties such as $\mathrm{pH}$ and water content and according to Henry's law, HONO can be released (Donaldson et al., 2014b; Su et al., 2011). This is consistent with field flux measurements showing HONO emission from the ground rather than deposition as is the case for $\mathrm{HNO}_{3}$ (Harrison and Kitto, 1994; Kleffmann et al., 2003; Ren et al., 2011; Stutz et al., 2002; VandenBoer et al., 2013, 2014; Villena et al., 2011; Zhou et al., 2011). In a recent study, Weber et al. (2015) measured large HONO and NO emissions from dryland soils with microbial surface communities (so-called biological soil crusts). Many studies have shown decreasing HONO mixing ratios with altitude in the lowest few hundred meters of the troposphere, due to respective short atmospheric lifetime compared to vertical transport time (Wong et al., 2012, 2013; Vogel et al., 2003; VandenBoer et al., 2013, 2014; Zhang et al., 2009; Young et al., 2012). According to the modeling results of Wong et al. (2013), we estimate that the ground HONO source could be important for up to 200$300 \mathrm{~m}$ a.g.l. This indicates that HONO is more relevant for the $\mathrm{OH}$ budget close to the surface than in high-altitude air masses.

Several field studies also show a correlation of the unknown HONO source with solar radiation or the photolysis frequency of $\mathrm{NO}_{2} \mathrm{~J}_{\mathrm{NO}_{2}}$ (Su et al., 2008a; Soergel et al., 2011a; Wong et al., 2012; Costabile et al., 2010; Michoud et al., 2014; Oswald et al., 2015; Lee et al., 2016). This correlation can be explained either by the aforementioned photosensitized reactions or by temperature-dependent soilatmosphere exchange (Su et al., 2011). According to Su et al. (2011), the release of HONO from soil surfaces is controlled by both the soil (biogenic and chemical) production of nitrite and the gas-liquid-phase equilibrium. The solubility is strongly temperature-dependent, resulting in higher HONO emissions during noontime and high-radiation $J_{\mathrm{NO}_{2}}$ periods, and lower HONO emissions or even HONO deposition during the nighttime as further confirmed by VandenBoer et al. (2015). This temperature dependence exists not only for equilibrium over soil solution but also for adsorptiondesorption equilibrium over dry and humid soil surfaces ( $\mathrm{Li}$ et al., 2016).

In this study we measured HONO and a suite of other atmospherically relevant trace gases in a coastal area on the Mediterranean island of Cyprus in summer 2014. Due to low local anthropogenic impact and low $\mathrm{NO}_{x}$ levels in aged air masses, but high solar radiation, this is an ideal site at which 
to investigate possible HONO sources and to gain a better understanding of HONO chemistry.

\section{Instrumentation}

HONO was measured with a commercial long-path absorption photometry instrument (effective light path $1.5 \mathrm{~m}$, LOPAP, Quma, Wuppertal, Germany). LOPAP has a collecting efficiency of $>99 \%$ for HONO and a detection limit of $4 \mathrm{pptv}$ at a time resolution of $30 \mathrm{~s}$. To avoid potential interferences induced by long inlet lines and heterogeneous formation or loss of HONO on the inlet walls (Kleffmann et al., 1998; Zhou et al., 2002b; Su et al., 2008b), HONO was collected by a sampling unit installed directly in the outdoor atmosphere, i.e., placed on a mast at a height of $5.8 \mathrm{~m}$ above ground installed at the edge of a laboratory container. Furthermore, the LOPAP has two stripping coils placed in series to reduce known interfering signals (Heland et al., 2001). In the first stripping coil HONO is quantitatively collected. Due to the acidic stripping solution, interfering species are collected less efficiently but in both channels. The true concentration of HONO is obtained by subtracting the inferences quantified in the second channel (in this study the average is 1 pptv, at most 5 pptv) from the total signal obtained from the first channel. For a more detailed description of LOPAP, see Heland et al. (2001). This correction of chemical interferences ascertained excellent agreement with the (absolute) differential optical absorption spectroscopy (DOAS) measurements, both in a smog chamber and under urban atmospheric conditions (Kleffmann et al., 2006). A possible interference from peroxynitric acid $\left(\mathrm{HNO}_{4}\right)$ has been proposed (Liao et al., 2006; Kerbrat et al., 2012; Legrand et al., 2014), but this will be insignificant at the high temperatures during the CYPHEX (CYprus PHotochemical EXperiment) campaign, at which $\mathrm{HNO}_{4}$ is unstable. The stripping coils are temperature-controlled by a water-based thermostat, and the whole external sampling unit is shielded from sunlight by a small plastic housing. The reagents were all highpurity-grade chemicals, i.e., hydrochloric acid (37\%, for analysis; Merck), sulfanilamide (for analysis, > 99\%; AppliChem) and N-(1-naphthyl)-ethylenediamine dihydrochloride (for analysis, $>98 \%$; AppliChem). For calibration Titrisol ${ }^{\circledR} 1000 \mathrm{mg} \mathrm{NO}_{2}^{-}\left(\mathrm{NaNO}_{2}\right.$ in $\mathrm{H}_{2} \mathrm{O}$; Merck) was diluted to 0.0015 and $0.005 \mathrm{mg} \mathrm{L}^{-1} \mathrm{NO}_{2}^{-}$. For preparation all solutions were used, and for cleaning of the absorption tubes $18 \mathrm{M} \Omega \mathrm{H}_{2} \mathrm{O}$ was used. The accuracy of the HONO measurements was $10 \%$, based on the uncertainties of liquid and gas flow, concentration of calibration standard and regression of calibration.

$\mathrm{NO}$ and $\mathrm{NO}_{2}$ measurements were made with a modified commercial chemiluminescence detector (CLD 790 SR), originally manufactured by ECO Physics (Duernten, Switzerland). The two-channel CLD based on the chemiluminescence of the reaction between $\mathrm{NO}$ and $\mathrm{O}_{3}$ was used for measurements of $\mathrm{NO}$ and $\mathrm{NO}_{2} . \mathrm{NO}_{2}$ was measured as NO using a photolytic converter from Droplet Measurement Technologies (Boulder, USA). In the current study, data were obtained at a time resolution of $5 \mathrm{~s}$. The CLD detection limits (determined by continuously measuring zero air at the measuring site) for $\mathrm{NO}$ and $\mathrm{NO}_{2}$ measurements were 5 and 20 pptv, respectively for an integration period of $5 \mathrm{~s} . \mathrm{O}_{3}$ was measured with a standard UV photometric detector (Model 49, Thermo Environmental Instruments Inc.) with a detection limit of $1 \mathrm{ppb}$. Data are reported for an integration period of $60 \mathrm{~s}$. The total uncertainties $(2 \sigma)$ for the measurements of $\mathrm{NO}, \mathrm{NO}_{2}$ and $\mathrm{O}_{3}$ were determined to be 20,30 and $5 \%$, respectively, based on the reproducibility of in-field background measurements, calibrations, the uncertainties of the standards and the conversion efficiency of the photolytic converter (Li et al., 2015).

$\mathrm{OH}$ and $\mathrm{HO}_{2}$ radicals were measured using the HydrOxyl Radical measurement Unit based on fluorescence Spectroscopy (HORUS) setup developed at the Max Planck Institute for Chemistry (Mainz, Germany). HORUS is based on laser-induced fluorescence-fluorescence assay by gas expansion (LIF-FAGE) technique, wherein $\mathrm{OH}$ radicals are selectively excited at low pressure by pulsed UV light at around $308 \mathrm{~nm}$, and the resulting fluorescence of $\mathrm{OH}$ is detected using gated microchannel plate (MCP) detectors (Martinez et al., 2010; Hens et al., 2014). The HORUS instrument had an inlet pre-injector (IPI) (Novelli et al., 2014) which allows the periodic addition of propane to scavenge the atmospheric $\mathrm{OH}$ radicals. This procedure allows the removal of potential interference species. $\mathrm{HO}_{2}$ is estimated by converting atmospheric $\mathrm{HO}_{2}$ into $\mathrm{OH}$ using $\mathrm{NO}$ and detecting the additional $\mathrm{OH}$ formed. The instrument is calibrated by measuring signals from known amounts of $\mathrm{OH}$ and $\mathrm{HO}_{2}$ generated by photolysis of water vapor in humidified zero air. The accuracy $(2 \sigma)$ of the $\mathrm{OH}$ measurements was $29 \%$, and the precision $(1 \sigma)$ was $4.8 \times 10^{5}$ molecules $\mathrm{cm}^{-3}$.

Photolysis frequencies were determined using a spectroradiometer (Metcon $\mathrm{GmbH}$ ) with a single monochromator and 512 pixel CCD array as a detector $(275-640 \mathrm{~nm})$. The thermostatted monochromator-detector unit was attached via a $10 \mathrm{~m}$ optical fiber to a $2-\Pi$ integrating hemispheric quartz dome. The spectroradiometer was calibrated prior to the campaign using a $1000 \mathrm{~W}$ National Institute of Standards and Technology (NIST) traceable irradiance standard. $J$ values were calculated using molecular parameters recommended by the IUPAC and NASA evaluation panels (Sander et al., 2011; IUPAC, 2015). The $J$ value for HONO was not corrected for upwelling UV radiation and is estimated to have an uncertainty of 10\% (Bohn et al., 2008).

Aerosol measurements were also performed during the campaign. In this study particulate nitrate and aerosol surface data were used. These were detected by high-resolution timeof-flight aerosol mass spectrometer (HR-ToF-AMS, Aerodyne Research Inc., Billerica, MA USA), and scanning mobility particle sizer (SMPS 3936, TSI, Shoreview, MN USA) 


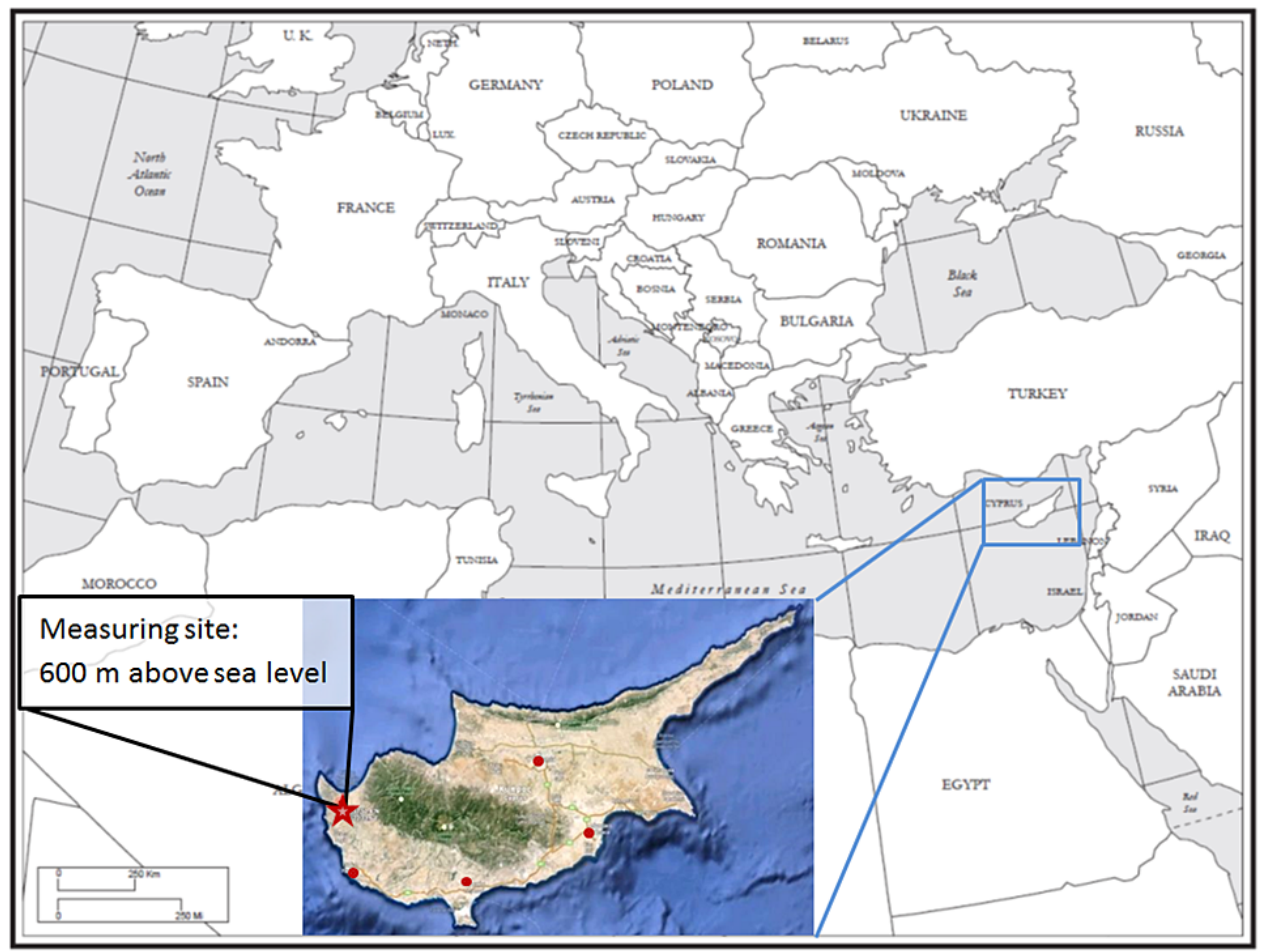

Figure 1. Map of location: the red star shows the location of Ineia and the measuring site. The four red points mark the main cities of Cyprus: Nicosia, Larnaca, Limassol and Paphos (clockwise ordering). Map produced by the Cartographic Research Lab University of Alabama; map of Cyprus: Google Maps.

and aerodynamic particle sizer (APS 3321, TSI), respectively. The mobility- and aerodynamics-based size distributions were combined based on the algorithm proposed by Khlystov et al. (2004).

The VOCs including $\alpha$-pinene, $\beta$-pinene, isoprene, $\Delta 3$ carene, limonene and DMS (dimethyl sulfide) were detected by a commercial gas chromatography-mass spectrometry (GC-MS) system (MSD 5973; Agilent Technologies GmbH) coupled with an air sampler and a thermal desorber unit (Markes International $\mathrm{GmbH}$ ). The VOCs were trapped at $30^{\circ} \mathrm{C}$ on a low-dead-volume quartz cold trap (U-T15ATA; Markes International $\mathrm{GmbH}$ ) filled with two-bed sorbent (Tenax TA and Carbograph I). The cold trap was heated to $320^{\circ} \mathrm{C}$, and the sample was transferred to a $30 \mathrm{~m} \mathrm{GC}$ column (DB-624, $0.25 \mathrm{~mm}$ I.D., $1.4 \mu \mathrm{m}$ film; J\&W Scientific). The temperature of the $\mathrm{GC}$ oven was programmed to be stable at $40^{\circ} \mathrm{C}$ for $5 \mathrm{~min}$ and then rise at a rate of $5^{\circ} \mathrm{C} \mathrm{min}^{-1}$ up to $140^{\circ} \mathrm{C}$. Thereafter, the rate was increased to $40^{\circ} \mathrm{C} \mathrm{min}-1$ up to $230^{\circ} \mathrm{C}$, where it was stabilized for $3 \mathrm{~min}$. Each sample was taken every $45 \mathrm{~min}$; calibrations, using a commercial gas standard mixture (National Physical Laboratory, UK), were performed every 8-12 samples.

Carbon monoxide was measured by infrared absorption spectroscopy using a room temperature quantum cascade laser at a time resolution of $1 \mathrm{~s}$. Data are reported as $60 \mathrm{~s} \mathrm{av-}$ erages with a total uncertainty of $\sim 10 \%$, mainly determined by the uncertainty of the NIST standard used (Li et al., 2015).

Meteorological parameters (temperature, relative humidity $(\mathrm{RH})$, wind speed and direction, pressure, solar radiation, precipitation) were detected by the weather station Vantage Pro2 from Davis Instruments.

Besides GC-MS all other operating instruments had time resolutions between $20 \mathrm{~s}$ and $5 \mathrm{~min}$. For most analyses in this study the data were averaged to $10 \mathrm{~min}$. When GC-MS data were included in the evaluation, $1 \mathrm{~h}$ averaged data were used.

\section{Site description}

Cyprus is a $9251 \mathrm{~km}^{2}$ island in the southeast Mediterranean Sea (Fig. 1). The measuring site was located on a military compound in Ineia, Cyprus ( $\left.34.9638^{\circ} \mathrm{N}, 32.3778^{\circ} \mathrm{E}\right)$, about $600 \mathrm{~m}$ above sea level and approximately $5.5-8 \mathrm{~km}$ from the coastline (main wind direction: W-SW). The field site is characterized by light vegetation cover, mainly comprising small shrubs like Pistacia lentiscus, Sarcopoterium spinosum and Nerium oleander; herbs like Inula viscosa and Foeniculum vulgare; and few typical Mediterranean trees like Olea europaea, Pinus sp. and Ceratonia siliqua. The area within a radius of about $15 \mathrm{~km}$ around the station is only weakly populated. Paphos (88 266 citizens) is located $20 \mathrm{~km}$ south of the field site; Limassol (235 000), Nicosia (325 756) and 
(a)
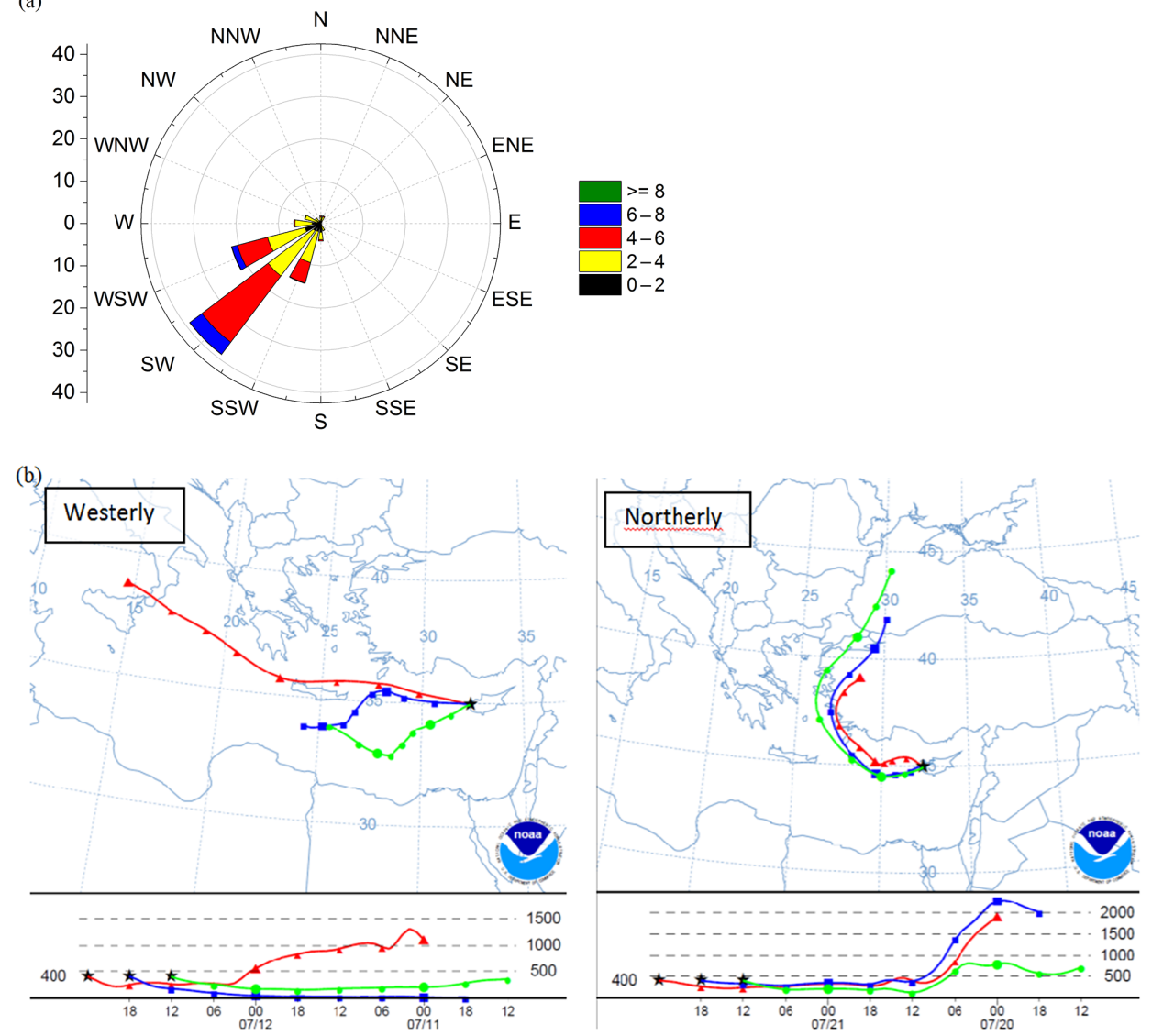

Figure 2. Airflow conditions during the CYPHEX campaign: (a) measured local wind direction, (b) back trajectories calculated with NOAA Hysplit model showing examples for the two main air mass origins $(48 \mathrm{~h}, \mathrm{UTC}=\mathrm{LT}-3 \mathrm{~h})$.

Larnaca (143 367) are 70, 90 and $110 \mathrm{~km}$ to the E-SE, respectively (population data according to statistical service of the Republic of Cyprus, http://www.cystat.gov.cy, census of population October 2011). During the campaign (7 July3 August 2014), clear-sky conditions prevailed and occasionally clouds skimmed the site. No rain was observed, but the elevated field site was impacted by fog during nighttime and early morning due to adiabatic cooling of ascending marine humid air masses. Temperature ranged from 18 to $28^{\circ} \mathrm{C}$. Within the main local wind direction of SW (Fig. 2a) there was no direct anthropogenic influence, resulting in clean humid air from the sea. Analysis of $48 \mathrm{~h}$ back trajectories showed mainly two source regions of air mass origin (Fig. 2b). For approximately half (46\%) of the campaign the air masses came from west of Cyprus, spending most of their time over the Mediterranean Sea prior to arriving at the site. During the remaining half of the campaign air masses originated from north of Cyprus, from eastern European countries (Turkey, Bulgaria, Rumania, Ukraine and Russia). Westerly air masses have been shown to exhibit lower concentration of gaseous and aerosol pollutants than the predominant northerly air masses that typically reach the site (Kleanthous et al., 2014). They spent more time over continental terrestrial surface and were likely to be additionally affected by biomass burning events detected in eastern Europe within the measurement periods (FIRMS, MODIS, web fire mapper, Fig. S1 in the Supplement). Previous back-trajectory studies in the eastern Mediterranean support this assumption (Kleanthous et al., 2014; Pikridas et al., 2010).

Most of the time the advected air mass was loaded with high humidity as a result of sea breeze circulation. Two periods of about 4 days with lower relative humidity occurred. These two situations will be contrasted below.

\section{Results}

The concentrations of $\mathrm{HONO}$ and other atmospheric trace gases as well as meteorological conditions observed on Cyprus from 7 July to 3 August 2014 are shown in Fig. 3. In general, low trace gas mixing ratios were indicative of clean marine atmospheric boundary conditions, as pollutants are oxidized by $\mathrm{OH}$ during the relatively long air transport time over the Mediterranean Sea (more than $30 \mathrm{~h}$ ), and without significant impact of direct anthropogenic emissions. 

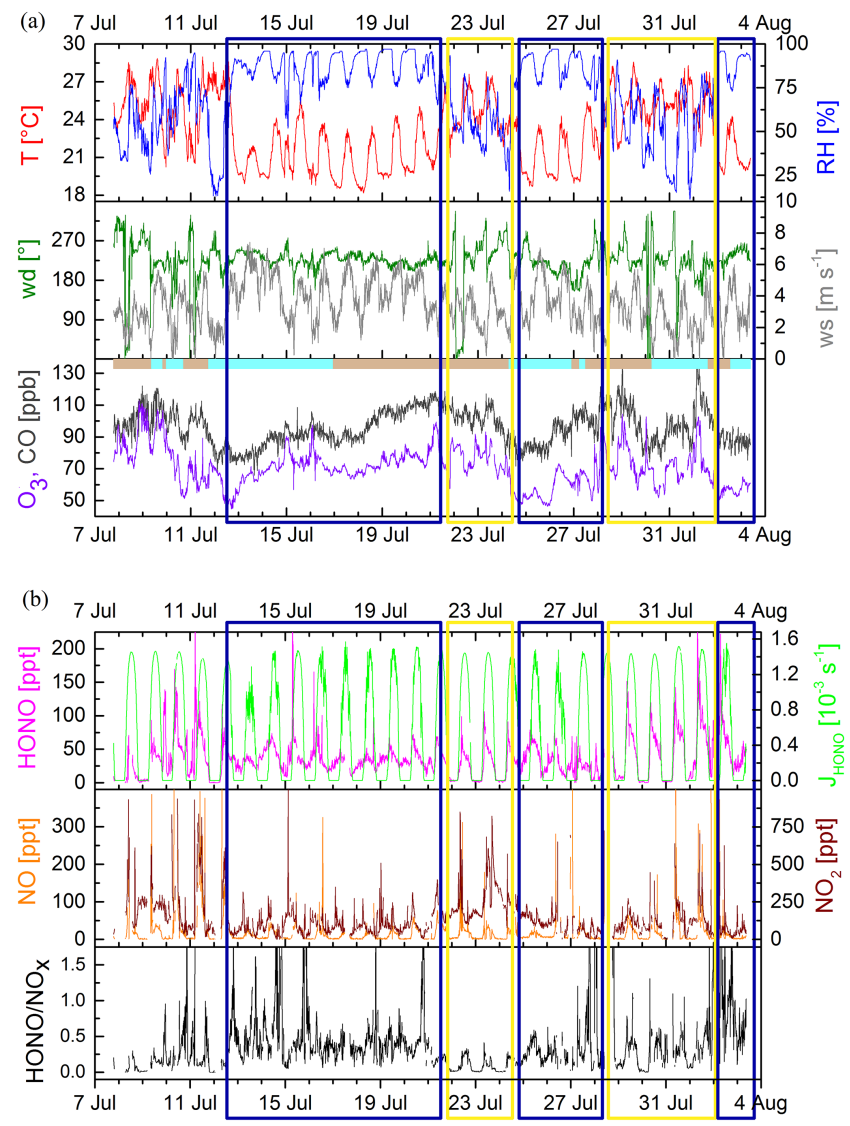

Figure 3. Measured variables during the whole campaign from 7 July to 4 August 2014. (a) Meteorological data (temperature, $T$; relative humidity, $\mathrm{RH}$; wind direction, wd; wind speed, ws), $\mathrm{O}_{3}$ and $\mathrm{CO}$ indicate stable conditions; in the lower panel the bar indicates the air mass origin: bright blue represents westerly, while the brownish color represents northerly. (b) Observed mixing ratios of $\mathrm{HONO}, \mathrm{NO}_{2}$ and $\mathrm{NO}$, and the photolysis frequency $J_{\mathrm{HONO}}$ and the HONO $/ \mathrm{NO}_{x}$ ratio. The yellow and blue boxes reflect the dry and the humid periods, respectively.

Ambient HONO mixing ratios ranged from below detection limit $(<4 \mathrm{pptv})$ to above $300 \mathrm{pptv}$. Daily average HONO was $35 \mathrm{pptv}$ ( $\pm 25 \mathrm{pptv} ; 1 \sigma$ standard deviation). The daily average $\mathrm{NO}_{2}$ and $\mathrm{NO}$ mixing ratios were $140 \pm 115$ and $20 \pm 35$ pptv, respectively, but showed intermittent peaks up to $50 \mathrm{ppbv}$ when sampling air was streamed from the diesel generator used to power the station, from the access route or the parking lot by local winds (easterly, Fig. S2). These incidents, which account for $4 \%$ of the campaign time, were classified as local air pollution events and were omitted from analysis. Mean $\mathrm{O}_{3}$ and $\mathrm{CO}$ mixing ratios were $72 \pm 12 \mathrm{ppb}$ and $98 \pm 11 \mathrm{ppbv}$, respectively. $\mathrm{OH}$ radicals ranged from below detection limit $\left(1 \times 10^{5}\right.$ molecules $\left.\mathrm{cm}^{-3}\right)$ during nighttime to $8 \times 10^{6}$ molecules $\mathrm{cm}^{-3}$ during daytime (see Fig. S3). Daytime $\mathrm{HO}_{2} / \mathrm{OH}$ ratio ranged from 100 to 150. The mixing ratios of $\mathrm{NO}_{2}, \mathrm{O}_{3}$ and $\mathrm{CO}$ varied in uni- son and were significantly $(p<0.05)$ higher during periods when air masses originated from eastern Europe (brownish bar in Fig. 3a, lower panel), indicative of air pollution and shorter transport times compared to western Europe $\left(\mathrm{NO}_{2}\right.$ : northerly: $144 \pm 130 \mathrm{pptv}$, westerly: $127 \pm 106 \mathrm{pptv}$; $\mathrm{O}_{3}$ : northerly: $74 \pm 11 \mathrm{ppbv}$, westerly: $66 \pm 12 \mathrm{ppbv}$; $\mathrm{CO}$ : northerly: $101 \pm 9 \mathrm{ppbv}$, westerly: $90 \pm 10 \mathrm{ppbv}$ ). In contrast, NO and HONO mixing ratios were slightly higher when air masses came from western Europe and over the sea (NO: northerly: $17 \pm 35$ pptv, westerly: $20 \pm 44$ pptv; HONO: northerly: $32 \pm 26$ pptv, westerly: $38 \pm 22$ pptv).

Besides two different air mass origins, two periods with different behavior of relative humidity were identified, as illustrated by blue and yellow boxes in Fig. 3a and b. In both periods we found northerly and westerly air mass origins. The diel profiles of trace gas mixing ratios and meteorological variables of the humid period (blue box) are shown in Fig. 4a, and the ones of the dry period (yellow box) in Fig. 4b. During the drier period HONO concentrations were stable and low (6 pptv) during nighttime, while mean nighttime HONO mixing ratios during the humid period (Fig. 4a) showed an expected slow increase of about $20 \mathrm{pptv}$ (from 20 to $40 \mathrm{pptv}$ ), as anticipated from heterogeneous production and accumulation within a nocturnal boundary layer characterized by a stable stratification and low wind speed (Acker et al., 2005; Su et al., 2008b; Li et al., 2012). During both periods, but more pronounced in the drier period, HONO rapidly increased by a factor of 2 within $2 \mathrm{~h}$ after sunrise and then slowly decreased until sunset. Similar profiles were also observed for other trace gases, like isoprene or DMS, which are transported in upslope winds. Strong HONO morning peaks and high daytime mixing ratios suggest a strong daytime source, compensating the short atmospheric lifetime (15 min) caused by fast photolysis.

Mean NO mixing ratios were close to the detection limit (5 pptv) at night and increased after sunrise (06:00 local time, LT) to mean values of $60 \mathrm{pptv}$ (peak $150 \mathrm{pptv}$ ) at 09:00 LT, prior to declining for the rest of the day until sunset (20:00 LT). In the absence of local NO sources low nighttime values are a result of the conversion of $\mathrm{NO}$ to $\mathrm{NO}_{2}$ by $\mathrm{O}_{3}$, which was continuously high (Hosaynali Beygi et al., 2011). The diel profiles of NO mixing ratios followed closely those of HONO mixing ratios. This similarity and their dependency on relative humidity are suggestive of a common source for both reactive nitrogen species.

$\mathrm{NO}_{2}$ mixing ratios were somewhat lower during nighttime, but in general the diel variability remained in a narrow range between 100 and 200 pptv. Likewise, the diel courses of $\mathrm{O}_{3}$ and $\mathrm{CO}$ mixing ratios revealed relatively low day-night variability in a range of $65-75$ and $90-100 \mathrm{ppb}$, respectively. 
(a)

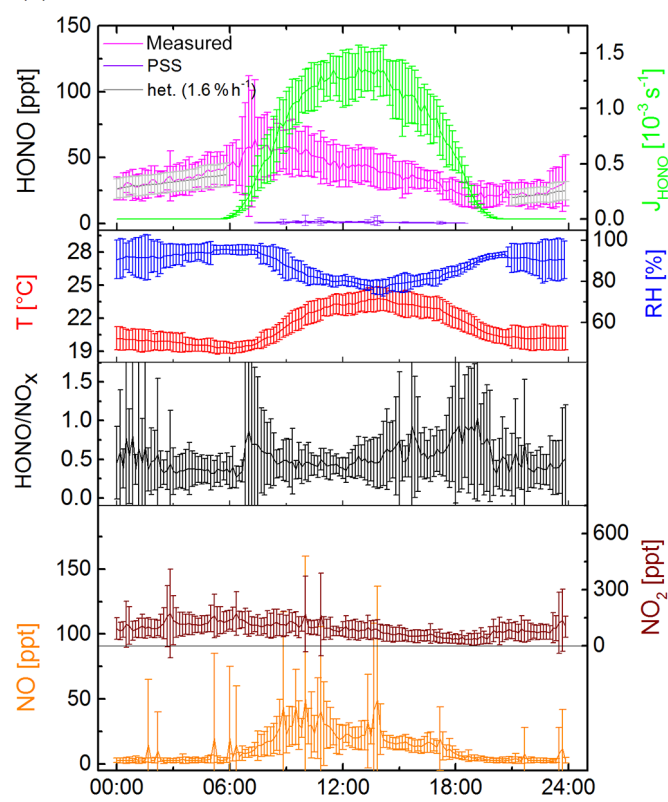

(b)

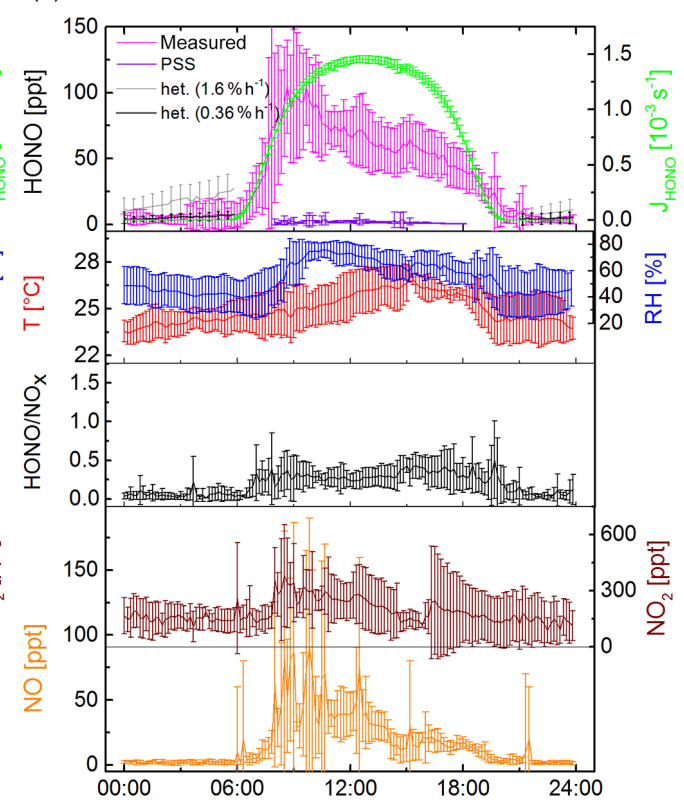

Figure 4. Diel variation of meteorological data (temperature, $T$; relative humidity, $\mathrm{RH}$ ), $\mathrm{NO}$ and $\mathrm{NO}_{2}$ mixing ratios, the photolysis rate for HONO $J_{\mathrm{HONO}}$ and $\mathrm{HONO}$ mixing ratios (pink: measured; violet: daytime photostationary state (PSS); grey: nighttime heterogeneous $\mathrm{NO}_{2}$ conversion) and $\mathrm{HONO} / \mathrm{NO}_{x}$ ratio for (a) average for period when $\mathrm{RH}$ was above $60 \%$ (blue box in Fig. 3) and (b) average for dry period when RH was below $60 \%$ (yellow box in Fig. 3). Error bars represent standard deviation of diel mean.

\section{Discussion}

Low- $\mathrm{NO}_{x}$ conditions at this remote field site in photochemically aged marine air were found to be an ideal prerequisite to trace as yet undefined local HONO sources. On Cyprus, diel profiles of HONO showed peak values in the late morning and persistently high mixing ratios during daytime, as has been reported for some other remote regions (Acker et al., 2006a; Zhou et al., 2007; Huang et al., 2002). This is not the case for rural and urban sites, where atmospheric HONO mixing ratios are normally observed to continuously build up during nighttime, presumably due to heterogeneous reactions involving $\mathrm{NO}_{x}$ and decline in the morning due to strong photodissociation (e.g., Elshorbany et al., 2012, and references therein).

The diel HONO / $\mathrm{NO}_{x}$ ratio (Fig. $4 \mathrm{a}, \mathrm{b}$, third panel) shows consistently high values during the humid period (Fig. 4a) and significant diel variation for the dry case (Fig. 4b) with higher values during daytime. The ratio (average of 0.33 and peak values greater than 2) is higher than that reported for most other regions, suggesting a strong impact of local HONO sources. Elshorbany et al. (2012) investigated data from 15 different urban and rural field measurement campaigns around the globe, and came up with a robust representative mean atmospheric $\mathrm{HONO} / \mathrm{NO}_{x}$ ratio as low as 0.02 . However, high values were observed at remote mountain sites, with mean values of 0.23 (up to $\approx 0.5$ in the late morning; Zhou et al., 2007) or 0.2-0.4 at remote Arctic/polar sites (Li, 1994; Zhou et al., 2001; Beine et al., 2001; Jacobi et al., 2004; Amoroso et al., 2010). Legrand et al. (2014) observed HONO / $\mathrm{NO}_{x}$ ratios between 0.27 and 0.93 during experiments with irradiated Antarctic snow, depending on radiation wavelength, temperature and nitrate content. Elevated $\mathrm{HONO} / \mathrm{NO}_{x}$ ratios at low $\mathrm{NO}_{x}$ levels show the importance of HONO formation mechanisms other than heterogeneous $\mathrm{NO}_{x}$ reactions.

\subsection{Nighttime HONO accumulation}

Between 18:30 and 07:30 LT HONO has an atmospheric lifetime of more than $45 \mathrm{~min}$ and $[\mathrm{OH}]$ is low, just about $1 \times 10^{5}$ molecules $\mathrm{cm}^{-3}$, so that the calculation of HONO at photostationary state $[\mathrm{HONO}]_{\mathrm{pss}}$ (Reactions R1-R3) at night is not appropriate. Instead, nighttime HONO concentrations can be estimated due to heterogeneous reaction of $\mathrm{NO}_{2}$ described in Eq. (1) (Alicke et al., 2002, 2003; Su et al., 2008b; Sörgel et al., 2011b). Three studies in different environments from a rural forest region in eastern Germany (Sörgel et al., 2011b) and a non-urban site in the Pearl River Delta, China (Su et al., 2008b), to an urban, polluted site in Beijing (Spataro et al., 2013) found a conversion rate of about $1.6 \% \mathrm{~h}^{-1}\left(1.1-1.8 \% \mathrm{~h}^{-1}\right)$.

$$
[\mathrm{HONO}]_{\text {het }}=[\mathrm{HONO}]_{\text {evening }}+0.016 \mathrm{~h}^{-1}\left[\mathrm{NO}_{2}\right] \Delta t
$$

$[\mathrm{HONO}]_{\text {het }}$ denotes the accumulation of HONO by heterogeneous conversion of $\mathrm{NO}_{2},[\mathrm{HONO}]_{\text {evening }}$ the measured 
HONO concentration at 20:30 LT, $\left[\mathrm{NO}_{2}\right]$ the measured average $\mathrm{NO}_{2}$ concentration between 20:30 and 07:30 LT, and $\Delta t$ time span in hours.

Measured and calculated HONO mixing ratios are compared in Fig. 4 (upper panel). During the humid period, during nighttime the estimated (according Eq. 1; Fig. 4a, upper panel, grey line) and observed HONO mixing ratios are in good agreement $\left(R^{2}=0.9\right)$. During the drier period the observed HONO mixing ratios were lower than the ones calculated with a $\mathrm{NO}_{2}$ conversion rate of $1.6 \% \mathrm{~h}^{-1}$. Here the approach for the nighttime conversion frequency by, e.g., Alicke et al. (2002, 2003), Su et al. (2008b) or Sörgel et al. (2011b) $\left(\right.$ rate $\left.=\frac{\mathrm{HONO}_{t 2}-\mathrm{HONO}_{t 1}}{\Delta t \cdot \mathrm{NO}_{2}}\right)$ was used. The 7-day average conversion rate for the dry nights was $0.36 \% \mathrm{~h}^{-1}$ (Fig. 4b, upper panel, black line), comparable to results of Kleffmann et al. (2003) reporting a conversion rate of $6 \times 10^{-7} \mathrm{~s}^{-1}\left(0.22 \% \mathrm{~h}^{-1}\right)$ for rural forested land in Germany.

As already mentioned above, it is apparent that HONO mixing ratios under low-RH conditions during nighttime were much lower than under humid conditions, and HONO morning peaks were most pronounced (compare Fig. 4a and b: humid/dry). HONO (Donaldson et al., 2014a) and $\mathrm{NO}_{2}$ (Wang et al., 2012; Liu et al., 2015) uptake coefficients have recently been reported to be much stronger for dry soil and at low RH, respectively, which is in line with HONO on Cyprus being close to the detection limit on nights with low relative humidity. On the other hand, it has been shown on glass and on soil proxies that the yield of $\mathrm{HONO}$ formation from $\mathrm{NO}_{2}$ on surfaces is low under dry conditions but sharply increases at $\mathrm{RH}>30 \%$ (Liu et al., 2015) or $>60 \%$ (Finlayson-Pitts et al., 2003). On Cyprus the strong morning HONO peaks after dry nights were accompanied by an increase in relative humidity from 40 to $80 \%$. Deposited and accumulated $\mathrm{NO}_{2}$ on dry soil surfaces could be released as $\mathrm{HONO}$ at high rates under elevated-RH conditions. In contrast, in a humid regime HONO mixing ratios were continuously high during nighttime and showed less pronounced morning peaks, suggesting lower nighttime deposition of $\mathrm{NO}_{2}$ and lower $\mathrm{HONO}$ emissions in the morning, respectively.

As morning HONO peak mixing ratios were most pronounced after dry nights on Cyprus, our observations are to some extent contradictory to earlier results that have proposed that dew formation on the ground surface may be responsible for HONO nighttime accumulation in the aqueous phase, followed by release from this reservoir after dew evaporation the next morning (Zhou et al., 2002a; Rubio et al., 2002; He et al., 2006). We cannot rule out that the latter could have contributed to nighttime accumulation of HONO during humid conditions, as we had no means to measure dew formation at the site, and high daytime HONO mixing ratios were observed under all humidity regimes. However, kinetic models of competitive adsorption of trace gases and water onto particle surfaces predict exchange behavior explicitly distinct from the liquid phase (Donaldson et al., 2014a). The nitrogen composition in thin water films (few water molecular monolayers) is complex, including $\mathrm{HONO}, \mathrm{NO}, \mathrm{HNO}_{3}$, water-nitric acid complexes, $\mathrm{NO}_{2}^{+}$and $\mathrm{N}_{2} \mathrm{O}_{4}$ (FinlaysonPitts et al., 2003). With only small amounts of surface-bound water, nitric acid is largely undissociated $\mathrm{HNO}_{3}$ and is assumed to be stabilized upon formation of the $\mathrm{HNO}_{3}-\mathrm{H}_{2} \mathrm{O}$ complexes (hydrates), which have unique reactivity compared to nitric acid water aqueous solutions, where it is dissociated $\mathrm{H}^{+}$and $\mathrm{NO}_{3}^{-}$ions (Finlayson-Pitts et al., 2003). Likewise, HONO formation rates in surface-bound water are about 4 orders of magnitude larger than expected for the aqueous-phase reaction (Pitts et al., 1984).

Diel HONO profiles very similar to those on Cyprus with a late-morning maximum and late-afternoon/early-evening minimum have been observed at the Meteorological Observatory Hohenpeissenberg, a mountain-top site in Germany (Acker et al., 2006a) and by Zhou et al. (2007) at the summit of Whiteface Mountain in New York State. For the latter study, formation of dew could be ruled out as relative humidity was mostly well below saturation. Zhou et al. (2007) argued that the high HONO mixing ratios during morning and late morning can be explained by mountain up-slope flow of polluted air from the cities at the foot of the mountain that results from ground surface heating. On Cyprus the sea breeze, driven by the growing difference between sea and soil surface temperature, brings air to the site which interacted with the soil surface and vegetation and is loaded by respective trace gas emissions. This is endorsed by the simultaneous increase of DMS and isoprene, markers for transportation of marine air and emission by vegetation. In the late afternoon, when the surface cools, down-welling air from aloft would dominate, being less influenced by ground surface processes. Zhou et al. (2007) could show that noontime HONO mixing ratios and average $\mathrm{NO}_{y}$ during the previous $24 \mathrm{~h}$ period were strongly correlated, much better than instantaneous $\mathrm{HONO} / \mathrm{NO}_{y}$ or $\mathrm{HONO} / \mathrm{NO}_{x}$, which is in line with $\mathrm{N}$ accumulation on soil surfaces as discussed above.

\subsection{Daytime HONO budget}

During daytime (07:30 to 18:00 LT, with HONO lifetime being between 10 and $30 \mathrm{~min}$ ), [HONO$]_{\text {PSS }}$, the photostationary HONO concentration resulting from gas-phase chemistry, can be calculated according to Eq. (2) (Kleffmann et al., 2005):

$[\mathrm{HONO}]_{\mathrm{PSS}}=\frac{k_{1}[\mathrm{OH}][\mathrm{NO}]}{k_{2}[\mathrm{OH}]+J_{\mathrm{HONO}}}$,

where $k_{1}$ and $k_{2}$ are the temperature-dependent rate constants for the gas-phase HONO formation from $\mathrm{NO}$ and $\mathrm{OH}$ and the loss of $\mathrm{HONO}$ by reaction of $\mathrm{HONO}$ and $\mathrm{OH}$, respectively (Atkinson et al., 2004; e.g., at $23.0^{\circ} \mathrm{C}$ a typical temperature during this study $k_{1} \approx 1.36 \times 10^{-11} \mathrm{~cm}^{3} \mathrm{~s}^{-1} ; k_{2} \approx$ $\left.6.01 \times 10^{-12} \mathrm{~cm}^{3} \mathrm{~s}^{-1}\right) . J_{\mathrm{HONO}}$ is the photolysis frequency of 
(a)

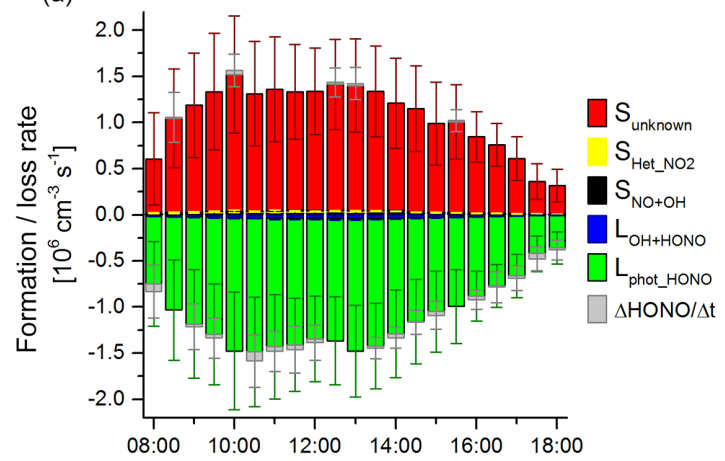

(b)

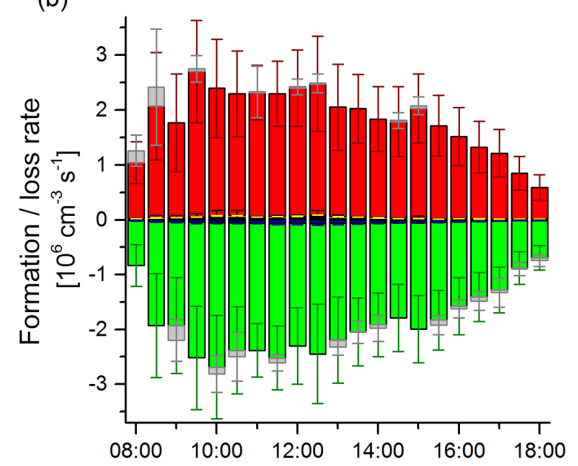

Figure 5. HONO budget analysis for (a) the humid and (b) the dry period. $S_{\mathrm{OH}+\mathrm{NO}}$ (black) stands for the formation rate of HONO via the reaction of NO and $\mathrm{OH}, S_{\mathrm{Het} \_\mathrm{NO}_{2}}$ (yellow) is the formation rate for the heterogeneous reaction of $\mathrm{NO}_{2}\left(\right.$ conversion rate $a=1.6 \% \mathrm{~h}^{-1}$; $b=0.36 \% \mathrm{~h}^{-1}$ ), $L_{\text {phot }}$ (green) and $L_{\mathrm{OH}+\mathrm{HONO}}$ (blue) are the loss rates via photolysis, and the reaction with $\mathrm{OH}$ and $S_{\text {unknown }}$ is the unknown source. Error bars indicate standard deviation of diel mean.

HONO, which was measured with a spectroradiometer. [NO] is the observed $\mathrm{NO}$ concentration. Since $\mathrm{OH}$ data were available only on a few days, diel variations of $[\mathrm{OH}]$ were averaged (see Fig. S3).

As has been previously established by many other studies (Su et al., 2008a; Michoud et al., 2014; Sörgel et al., 2011a), homogeneous gas-phase chemistry alone fails to reflect observed HONO mixing ratios. Observed daytime values were up to 30 times higher than calculated based on PSS, indicating strong additional local daytime sources of HONO. Lee et al. (2013) argue that the HONO PSS assumption might overestimate the strength of any unidentified source if the transport time from nearby $\mathrm{NO}_{x}$ emission sources to the measurement site is less than the time required for HONO to reach PSS. In this study, the missing source was calculated according to Su et al. (2008a) (Eq. 3), where PSS was not assumed. Also in our measurements, $\mathrm{dHONO} / \mathrm{d} t$ was not equal to 0 , as HONO was not at PSS.

$$
\begin{aligned}
S_{\mathrm{HONO}} & =J_{\mathrm{HONO}}[\mathrm{HONO}]+k_{2}[\mathrm{OH}][\mathrm{HONO}] \\
& -k_{1}[\mathrm{OH}][\mathrm{NO}]-k_{\mathrm{het}}\left[\mathrm{NO}_{2}\right]+\frac{\Delta[\mathrm{HONO}]}{\Delta t}
\end{aligned}
$$

[HONO] is the measured HONO concentration and $k_{\text {het }}$ the heterogeneous conversion rate of $\mathrm{NO}_{2}$ to $\mathrm{HONO}$, which was discussed above to be $1.6 \% \mathrm{~h}^{-1}$ during the wet period and $0.36 \% \mathrm{~h}^{-1}$ during the dry period. $\Delta[\mathrm{HONO}] / \Delta t$ is the observed change of HONO concentration unequal to 0 . The uncertainty of the calculated missing source $S_{\mathrm{HONO}}$ was estimated to be about $16 \%$ based on the Gaussian error propagation of instrument uncertainties of $\mathrm{HONO}, \mathrm{NO}, \mathrm{NO}_{2}, J$ and $\mathrm{OH}$.

Nevertheless, at the study site of Cyprus, the mean upwind distance between the measurement site and the coastline was about $6 \mathrm{~km}$, and the mean wind velocity was about $3 \mathrm{~m} \mathrm{~s}^{-1}$. Accordingly, the respective air mass travel time over land is estimated to be about half an hour, which is somewhat longer than the daytime lifetime of HONO and might provide enough time for the equilibrium processes. Furthermore and in strong contrast to Lee et al. (2013), at the Cyprus site the concentrations of $\mathrm{HONO}$ precursors $(\mathrm{NO}$ and $\mathrm{OH})$ were extremely low, far too low to explain the observed HONO concentrations. In the late morning (around 10:00 LT) the unknown source was at its maximum, with peak production rates of up to $3.4 \times 10^{6}$ molecules $\mathrm{cm}^{-3} \mathrm{~s}^{1}$ and a daytime average of about $1.3 \times 10^{6} \mathrm{~cm}^{-3} \mathrm{~s}^{-1}$, which is in good agreement with other studies at rural sites, like a mountain site at Hohenpeissenberg $\left((3 \pm 1) \times 10^{6} \mathrm{~cm}^{-3} \mathrm{~s}^{-1}\right.$, at $\mathrm{NO}_{x} \approx$ 2 ppbv; Acker et al., 2006a), a deciduous forest site in Jülich $\left(3.45 \times 10^{6}\right.$ molecules $\mathrm{cm}^{-3} \mathrm{~s}^{-1}$, at NO $\approx 250$ pptv; Kleffmann et al., 2005) and a pine forest site in southwest Spain $0.74 \times 10^{6}$ molecules $\mathrm{cm}^{-3} \mathrm{~s}^{-1}$, at $\mathrm{NO}_{x} \approx 1.5 \mathrm{ppbv}$; Soergel et al., 2011a) but smaller than at urban sites in Houston (4-6 $\times 10^{6} \mathrm{~cm}^{-3} \mathrm{~s}^{-1}$, at $\mathrm{NO}_{x} \approx 6 \mathrm{ppbv}$; Wong et al., 2012), Beijing $\left(7 \times 10^{6} \mathrm{~cm}^{-3} \mathrm{~s}^{-1}\right.$, at $\mathrm{NO}_{x} \approx 15 \mathrm{ppbv}$; Yang et al., 2014) and southern China $\left(5.25 \pm 3.75 \times 10^{6} \mathrm{~cm}^{-3} \mathrm{~s}^{-1}\right.$, at $\mathrm{NO}_{x} \approx 20 \mathrm{ppbv}$ (Li et al., 2012), or $1-4 \times 10^{7} \mathrm{~cm}^{-3} \mathrm{~s}^{-1}$, at $\mathrm{NO}_{x} \approx 35$ ppbv (Su et al., 2008a)).

The contributions of gas-phase reactions and the heterogeneous reaction of $\mathrm{NO}_{2}$ (conversion rate $a 1.6 \% \mathrm{~h}^{-1}$ and $b 0.36 \% \mathrm{~h}^{-1}$ ) to the HONO budget are illustrated in Fig. 5 exemplarily. For both periods the contributions are quiet similar; just the absolute values are different. To compensate the strong loss via photolysis, a comparably strong unknown source is necessary as the heterogeneous $\mathrm{NO}_{2}$ conversion or the gas-phase reaction of $\mathrm{OH}$ and $\mathrm{NO}$ is insignificant.

In polluted regions with moderate to high $\mathrm{NO}_{x}$ concentrations, HONO sources have often been linked with $\left[\mathrm{NO}_{2}\right]$ or $\left[\mathrm{NO}_{x}\right]$ (Acker et al., 2005; Li et al., 2012; Levy et al., 2014; Sörgel et al., 2011a; Wentzel et al., 2010). Under the prevailing low- $\mathrm{NO}_{x}$ conditions during CYPHEX ( $\left.<250 \mathrm{pptv}\right)$, correlation analysis (see Table 1$)$ of $S_{\mathrm{HONO}}$ with $\left[\mathrm{NO}_{2}\right]\left(R^{2}=\right.$ $0.50)$ and $\left[\mathrm{NO}_{2}\right] \cdot \mathrm{RH}\left(R^{2}=0.51\right)$ indicate no significant im- 
Table 1. Linear correlation factors (Pearson correlation, $R^{2}$ ) of HONO and the unknown source $S_{\mathrm{HONO}}$ to meteorological factors and different $\mathrm{NO}_{x}$ parameters.

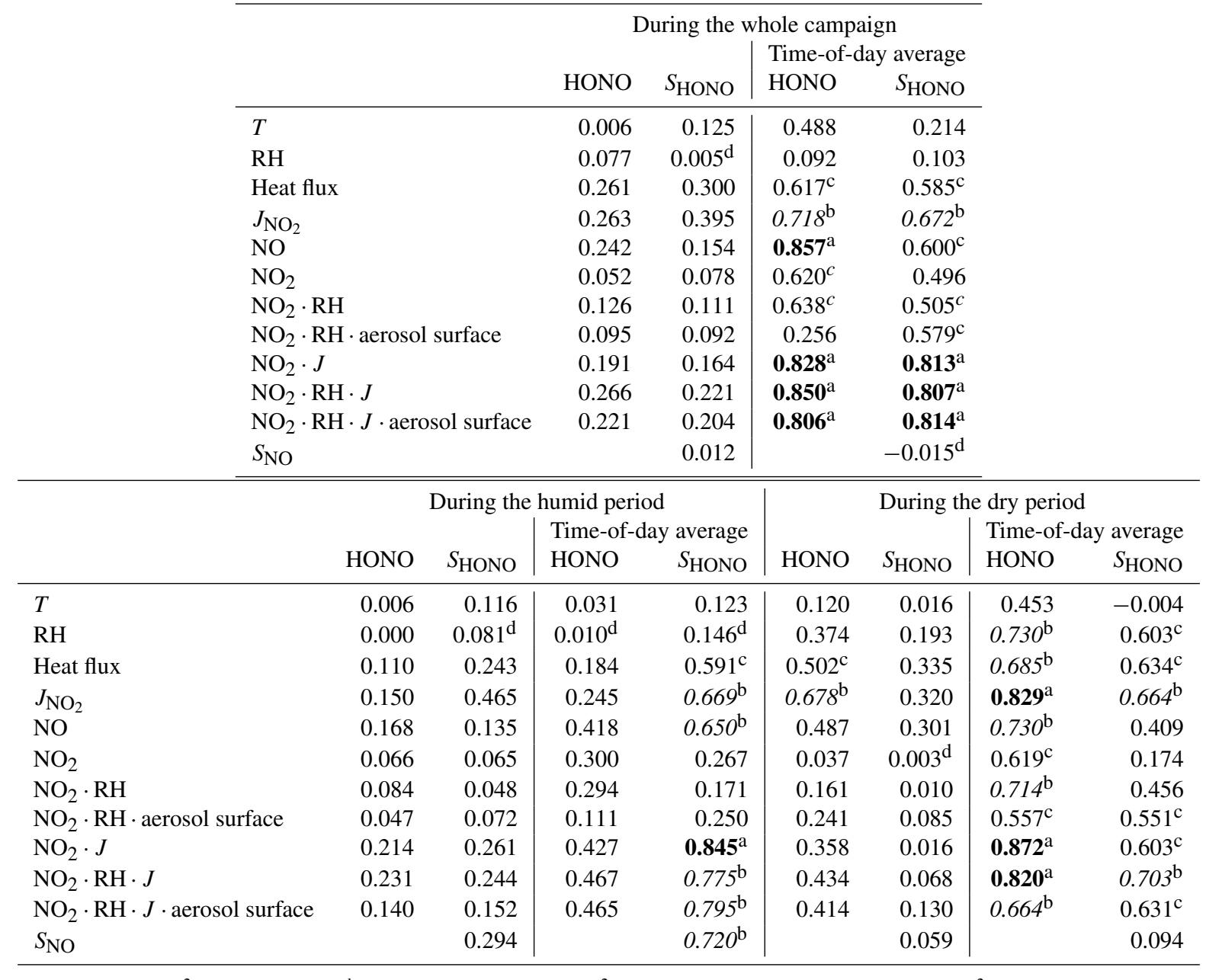

${ }^{\mathrm{a}}$ Highly correlated: $R^{2}>0.8$ (in bold font). ${ }^{\mathrm{b}}$ Moderately correlated: $0.65<R^{2}<0.8$ (in italic font). ${ }^{\mathrm{c}}$ Poorly correlated: $0.5<R^{2}<0.65$ (in normal font).

d Anti-correlated.

pact of instantaneous heterogeneous formation of HONO from $\mathrm{NO}_{2}$. Better correlations of $S_{\mathrm{HONO}}$ with $J_{\mathrm{NO}_{2}}\left(R^{2}=\right.$ $0.67)$ and $J_{\mathrm{NO}_{2}} \cdot\left[\mathrm{NO}_{2}\right]\left(R^{2}=0.82\right)$ indicate a photo-induced conversion of $\mathrm{NO}_{2}$ to $\mathrm{HONO}$ as already suggested by George et al. (2005) or Stemmler et al. (2006, 2007). Lee et al. (2016) found even lower correlation with $\left[\mathrm{NO}_{2}\right]\left(R^{2}=0.0001\right)$ but similar good correlation with $J_{\mathrm{NO}_{2}} \cdot\left[\mathrm{NO}_{2}\right]\left(R^{2}=0.70\right)$ at an urban background site in London. Other light-dependent reactions such as the photolysis of nitrate might additionally contribute to high daytime HONO. It is unlikely that aerosol surfaces played an important role in heterogeneous conversion of $\mathrm{NO}_{2}$ as the mean observed aerosol surface concentration was only about $300 \mu \mathrm{m}^{2} \mathrm{~cm}^{-3}$. Based on a formula for photo-enhanced conversion of $\mathrm{NO}_{2}$ on humic acid aerosols which was derived by Stemmler et al. (2007), a HONO formation rate of only $5.1 \times 10^{2}$ molecules $\mathrm{cm}^{-3} \mathrm{~s}^{-1}$ can be estimated. Likewise, Sörgel et al. (2015) showed that HONO fluxes from light-activated reactions of $\mathrm{NO}_{2}$ on humic acid surfaces at low $\mathrm{NO}_{2}$ levels $(<1 \mathrm{ppb}$ and thus comparable to concentrations observed in this study) saturated at around $0.0125 \mathrm{nmol} \mathrm{m}^{-2} \mathrm{~s}^{-1}$. Therefore heterogeneous aerosol surface reactions can be neglected as HONO sources at the prevailing low $\mathrm{NO}_{x}$ levels.

Likewise, the nitrate concentrations of highly acidic marine aerosols particulate matter as measured by HR-ToFAMS (PM1 fraction, mean of $0.075 \mu \mathrm{g} \mathrm{m}^{-3}$ ) were too low to account for significant photolytic HONO production $\left(1.7 \times 10^{2}\right.$ molecules $\mathrm{cm}^{-3} \mathrm{~s}^{-1}$ or $0.01 \%$ of $\left.S_{\mathrm{HONO}}\right)$ calculated by Eq. (4):

$S_{\text {photo_ } \mathrm{NO}_{3}^{-}}=\left[\overline{\mathrm{NO}_{3}^{-}}\right] \cdot J_{\mathrm{NO}_{3}^{-}}$,

with $S_{\text {photo_NO }}$ - being the source strength of HONO by photolysis of nitrate, $\left[\overline{\mathrm{NO}_{3}^{-}}\right]$the mean particulate nitrate concentration and $J_{\mathrm{NO}_{3}^{-}}$the photolysis frequency of nitrate (aqueous) at noon ( $3 \times 10^{-7} \mathrm{~s}^{-1}$; Jankowski et al., 1999). 
Recently an enhancement of the photolysis frequency of particulate nitrate relative to gaseous or aqueous nitrate was found (Ye et al., 2016). But even with this enhanced rate of $2 \times 10^{-4} \mathrm{~s}^{-1}$ no more than $1.1 \times 10^{5}$ molecules $\mathrm{cm}^{-3} \mathrm{~s}^{-1}$ ( $8 \%$ of $S_{\mathrm{HONO}}$ ) HONO would be produced.

\subsection{Common daytime source of HONO and NO}

During CYPHEX, good correlation was found between [HONO] or $S_{\mathrm{HONO}}$ and [NO] $\left(R^{2}=0.86\right.$ and 0.60 , respectively), indicating that both may have a common source. A missing source of NO can be calculated as shown in Eq. (5).

$$
\begin{aligned}
S_{\mathrm{NO}} & =k_{1}[\mathrm{OH}][\mathrm{NO}]+k_{3}\left[\mathrm{HO}_{2}\right][\mathrm{NO}]+k_{4}\left[\mathrm{O}_{3}\right][\mathrm{NO}] \\
& +k_{5}\left[\mathrm{RO}_{2}\right][\mathrm{NO}]-J_{\mathrm{NO}_{2}}\left[\mathrm{NO}_{2}\right]-J_{\mathrm{HONO}}[\mathrm{HONO}] \\
& +\frac{\Delta[\mathrm{NO}]}{\Delta t}
\end{aligned}
$$

$k_{3}$ and $k_{4}$ are the temperature-dependent rate constants for the reaction of $\mathrm{NO}$ with $\mathrm{HO}_{2}$ and $\mathrm{O}_{3}$, respectively (Atkinson et al., 2004; at $23^{\circ} \mathrm{C}: k_{3} \approx 8.96 \times 10^{-12} \mathrm{~cm}^{3} \mathrm{~s}^{-1} ; k_{4} \approx 1.68 \times$ $\left.10^{-14} \mathrm{~cm}^{3} \mathrm{~s}^{-1}\right) ; k_{5}$ is the rate constant for the reaction of NO and organic peroxy radicals which was assumed to be the same as for the reaction $\mathrm{NO}+\mathrm{CH}_{3} \mathrm{O}_{2}\left(7.7 \times 10^{-12} \mathrm{~cm}^{3} \mathrm{~s}^{-1}\right.$ at 298 K; Ren et al., 2010; Sander et al., 2011). Like [OH], $\left[\mathrm{HO}_{2}\right]$ was also measured only on a few days, and therefore mean diel data were used (Fig. S3). Total $\left[\mathrm{RO}_{2}\right]$ was estimated to be maximum $1.6 \cdot\left[\mathrm{HO}_{2}\right]$ (Ren et al., 2010; Hens et al., 2014). Using a $\mathrm{RO}_{2} / \mathrm{HO}_{2}$ ratio of 1.2 , the absolute values of $S_{\mathrm{NO}}$ are reduced by 0.3 to $5.5 \%$. The budget analysis for NO for both humidity regimes is illustrated in Fig. S4.

For $\mathrm{NO}_{x}$, an unexpected deviation from the PSS, or Leighton ratio, of clean marine boundary layer air has been observed previously, invoking a hitherto unknown NO sink, or pathway for $\mathrm{NO}$ to $\mathrm{NO}_{2}$ oxidation, other than reactions with $\mathrm{OH}, \mathrm{HO}_{2}, \mathrm{O}_{3}$ and organic peroxides (Hosaynali Beygi et al., 2011). On Cyprus, two different atmospheric humidity regimes can be differentiated. Under dry conditions ( $\mathrm{RH}<70 \%$, yellow boxes in Fig. 3 ) and higher $\mathrm{NO}_{x}$ concentrations ( $>150 \mathrm{pptv}) S_{\mathrm{NO}}$ is negative, implying a net NO sink of up to $6.4 \times 10^{7}$ molecules $\mathrm{cm}^{-3} \mathrm{~s}^{-1}$ resembling the abovementioned PSS deviations in remote marine air masses (see Figs. 6 and 7). However, during humid conditions $(\mathrm{RH}>70$, blue boxes in Fig. 3) $S_{\mathrm{NO}}$ was positive with values of up to $5.1 \times 10^{7}$ molecules $\mathrm{cm}^{-3} \mathrm{~s}^{-1}$. Due to low and invariant acetonitrile levels, anthropogenic activity and local biomass burning can be excluded as an NO source at this specific site. A net NO source during humid conditions is assumed to result from (biogenic) NO emission from soil. As shown in Fig. 8, the $S_{\mathrm{HONO}}$ and $S_{\mathrm{NO}}$ (time-of-day average, excluding 3 days as there are transition days (25 July and 2 August) or the RH changed too quickly (15 July)) were highly correlated $\left(R^{2}=0.72\right)$, indicative of both reactive $\mathrm{N}$ compounds being emitted from the same local source. Both HONO and NO have been reported to be released from soil, with a strong dependency on soil water content (Su et al., 2011; Oswald et

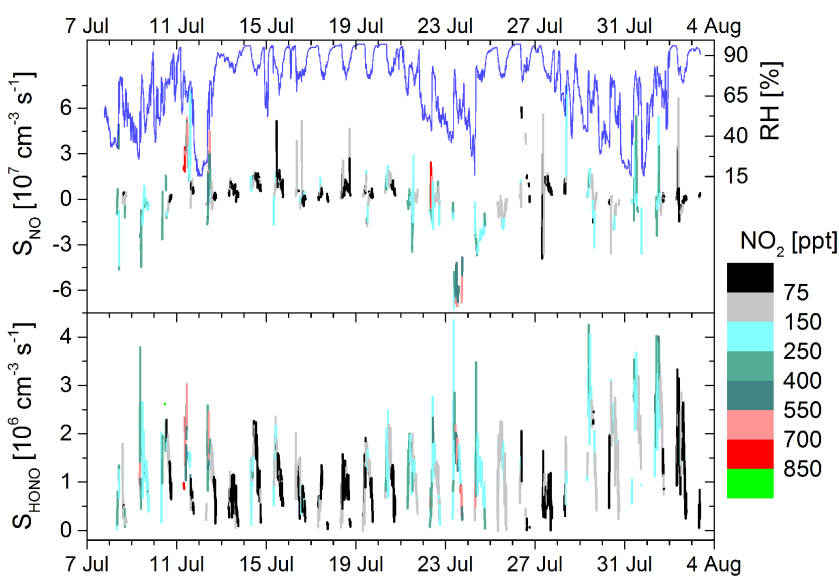

Figure 6. $\mathrm{NO}_{2}$ (color-coded) and $\mathrm{RH}$ dependence of the sources of $\mathrm{NO}\left(S_{\mathrm{NO}}\right)$ and $\mathrm{HONO}\left(S_{\mathrm{HONO}}\right)$.

al., 2013; Mamtimin et al., 2016). The (dry-state) soil humidification threshold level for NO emission is reported to be somewhat higher than for HONO (Oswald et al., 2013), which might explain why a net NO source was preferentially calculated for higher-relative-humidity conditions, while for HONO a daytime source under all humidity regimes prevailing during the campaign was found. Mamtimin et al. (2016) investigated HONO and NO emissions of natural desert soil and with grapes or cotton cultivation soils in an oasis in the Taklamakan Desert in the Xinjiang region in China. After irrigation they did not find direct emission, but when the soil had almost dried out (gravimetric soil water content: 0.010.3 ) emissions up to $115 \mathrm{ng} \mathrm{N} \mathrm{m}^{-2} \mathrm{~s}^{-1}$ were detected. In addition they observed soil-temperature-dependent emission of reactive nitrogen. Analyzing microbial surface communities from drylands, Weber et al. (2015) observed highly correlated NO-N and HONO-N emissions with Spearman rank correlation coefficients ranging between 0.75 and 0.99 . In this study, NO and HONO emissions were observed in drying soils with water contents of 20-30\% water holding capacity.

Even though we cannot make firm conclusions regarding the exact mechanism of HONO formation, the abovementioned correlation analysis (and Table 1) reveal that the instantaneous heterogeneous $\mathrm{NO}_{2}$ conversion is not a significant HONO source. We propose that HONO is emitted from nitrogen compounds being accumulated on mountain slope soil surfaces produced either biologically by soil microbiota or from previously deposited $\mathrm{NO}_{y}$. This forms the major daytime HONO source responsible for morning concentration peaks and consistently high daytime mixing ratios at the Cyprus field site. While biological formation is assumed to be more relevant for humid conditions, physical $\mathrm{NO}_{y}$ accumulation can be assumed to be stronger under dry conditions, as uptake coefficients for a variety of trace gases were shown to be significantly higher for dry surfaces, among them $\mathrm{NO}_{2}$ (Wang et al., 2012; Liu et al., 2015), HONO (Donaldson et 

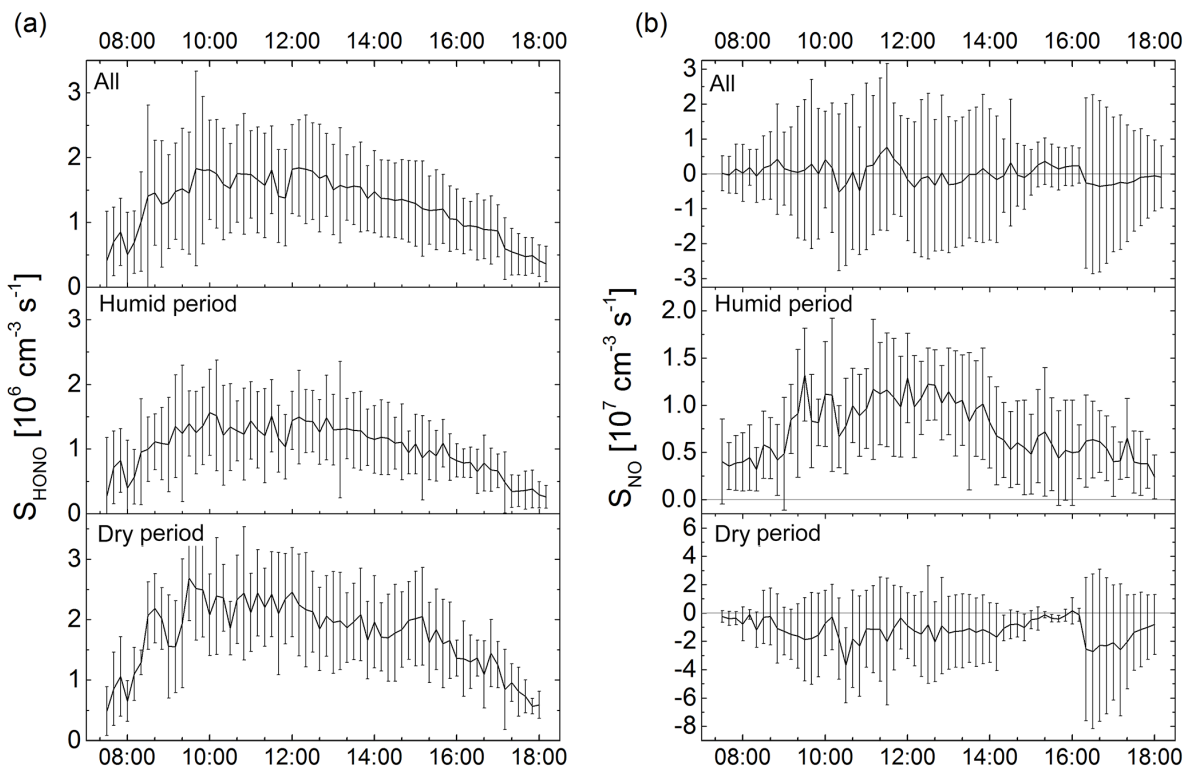

Figure 7. Diel profile of both unknown sources, $S_{\mathrm{HONO}}(\mathbf{a})$ and $S_{\mathrm{NO}}(\mathbf{b})$, for all data, humid (excluding transition days, 25 July and 2 August, and 15 July as RH conditions changed too quickly) and dry periods. Error bars indicate standard deviation of diel average.

al., 2014a) and HCHO (Li et al., 2016). The strongest HONO morning peaks observed after dry nights were accompanied by an increase in relative humidity driven by the sea breeze (Fig. 4b), so we consider HONO as being released preferentially under favorable humid conditions.

\subsection{Primary OH production}

Many studies showed high contribution of HONO photolysis to the $\mathrm{OH}$ budget (up to $30 \%$ on average daily; Alicke et al., 2002; Ren et al., 2006). Here, the primary $\mathrm{OH}$ production rates are calculated based on the main $\mathrm{OH}$-forming reactions, which are the photolysis of $\mathrm{O}_{3}$ and subsequent reaction with water (Reactions R6, R7), the photolysis of HONO (Reaction R2) and the reaction of alkenes with ozone (Reaction R8).

$\mathrm{O}_{3} \stackrel{h v(<340 \mathrm{~nm})}{\longrightarrow} \mathrm{O}\left({ }^{1} \mathrm{D}\right)+\mathrm{O}_{2}$

$\mathrm{O}\left({ }^{1} \mathrm{D}\right)+\mathrm{H}_{2} \mathrm{O} \rightarrow 2 \mathrm{OH}$

alkene $+\mathrm{O}_{3} \rightarrow \mathrm{OH}+$ other products

Reaction rates were taken from Atkinson et al. (2004) and Atkinson (1997). The water pressure over water was calculated according to Murphy and Koop (2005). Reactions of $\mathrm{O}\left({ }^{1} \mathrm{D}\right)$ and $\mathrm{HO}_{2}$ not forming $\mathrm{OH}$ are also considered. $\mathrm{OH}$ formation yields of the reactions of alkenes with $\mathrm{O}_{3}$ were taken from Paulson et al. (1999). Photolysis rates ( $J$ values) and concentrations of relevant compounds were as measured on Cyprus. Isoprene, $\alpha$-pinene, $\beta$-pinene, $\Delta 3$-carene and limonene (VOC) were taken into account as the most relevant alkenes.
The results of this study are shown in Fig. 9. All three production routes show a clear diel profile with higher production rates during daytime. In the night only the reaction of alkenes with $\mathrm{O}_{3}$ produced significant amounts of $\mathrm{OH}\left(2 \times 10^{4}\right.$ molecules $\left.\mathrm{cm}^{-3} \mathrm{~s}^{-1}\right)$. With sunrise the other sources become more relevant. During daytime the photolysis of HONO generates about $1.5 \times$ $10^{6}$ molecules $\mathrm{OH} \mathrm{cm}{ }^{-3} \mathrm{~s}^{-1}$, which is about 10 times higher than the ozonolysis of alkenes at that time. The maximum $\mathrm{OH}$ production rate by $\mathrm{O}_{3}$ photolysis during daytime is about $1.3 \times 10^{7}$ molecules $\mathrm{cm}^{-3} \mathrm{~s}^{-1}$. In the morning (06:0008:00 LT) and evening hours (19:00-20:00 LT) the contribution of $\mathrm{HONO}$ photolysis to the primary $\mathrm{OH}$ production is on average $37 \%$ (see Fig. 9b) with peak values of $65 \%$, which is much higher than the contribution of $\mathrm{O}_{3}$ photolysis at that time. During the rest of the day the contribution of HONO decreases to $12 \%$. At noon the most dominant $\mathrm{OH}$ source is the photolysis of $\mathrm{O}_{3}$ (more than $80 \%$ ), while the contribution of the ozonolysis of alkenes is almost negligible (1-2\%). A complete and detailed $\mathrm{HO}_{x}$ budget analysis with CYPHEX data will be published soon.

\section{Conclusion}

Nitrous acid was found in low concentrations on the east Mediterranean island of Cyprus during summer 2014. Daytime concentrations were much higher than during the night and about 30 times higher than would be expected by budget analysis based on photostationary state. The unknown source was calculated to be about $1.9 \times 10^{6}$ molecules $\mathrm{cm}^{-3} \mathrm{~s}^{-1}$ around noon. Low $\mathrm{NO}_{x}$ concentrations, high $\mathrm{HONO} / \mathrm{NO}_{x}$ 

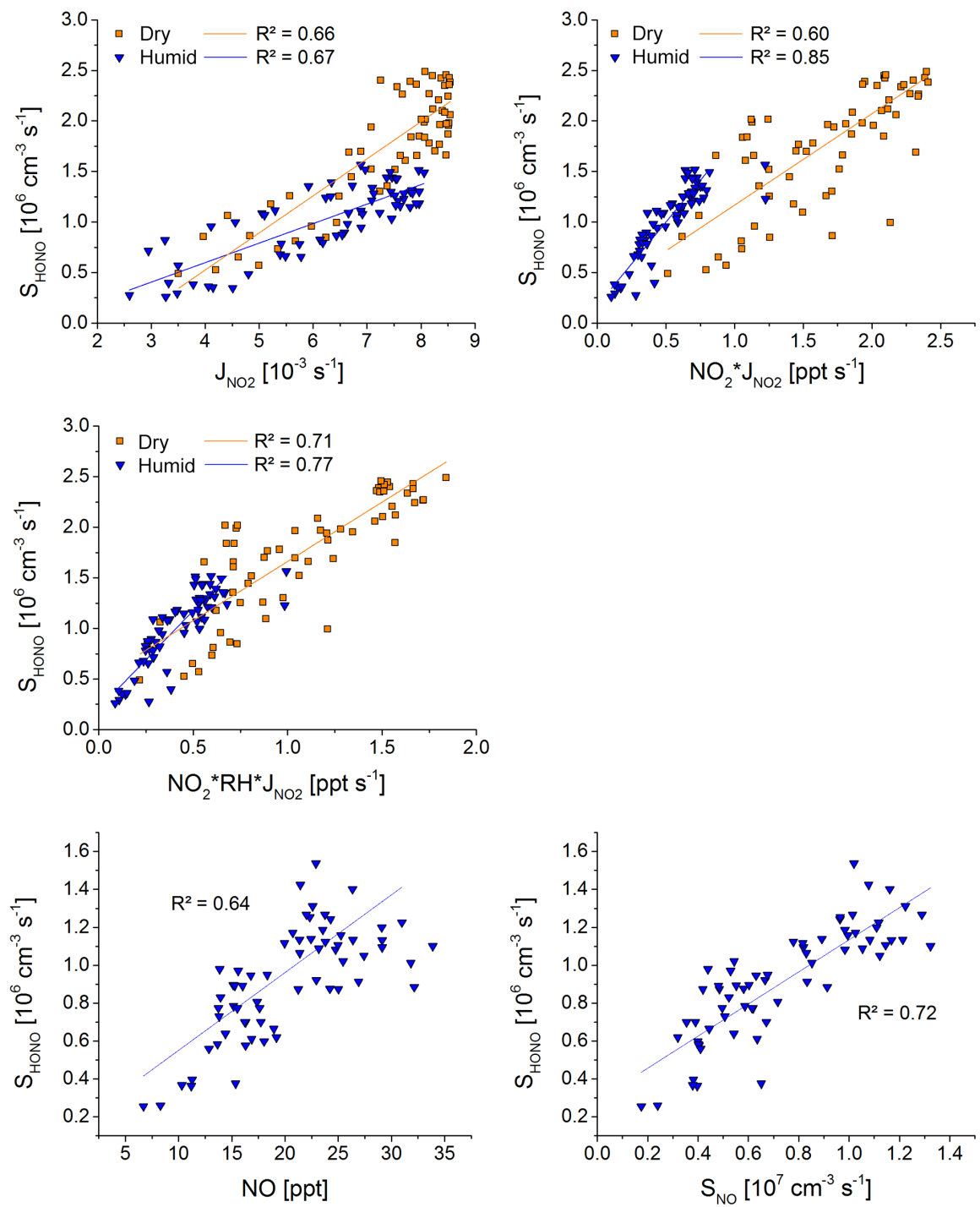

Figure 8. Correlation of $S_{\mathrm{HONO}}$ to light-induced $\mathrm{NO}_{2}$ reaction (for both periods; humid: blue triangle; dry: orange square), to NO and $S_{\mathrm{NO}}$ (only for humid period, excluding the transition days - 25 July and 2 August - and the day with quickly changing RH - 15 July); time-of-day-average data were used.

(a)

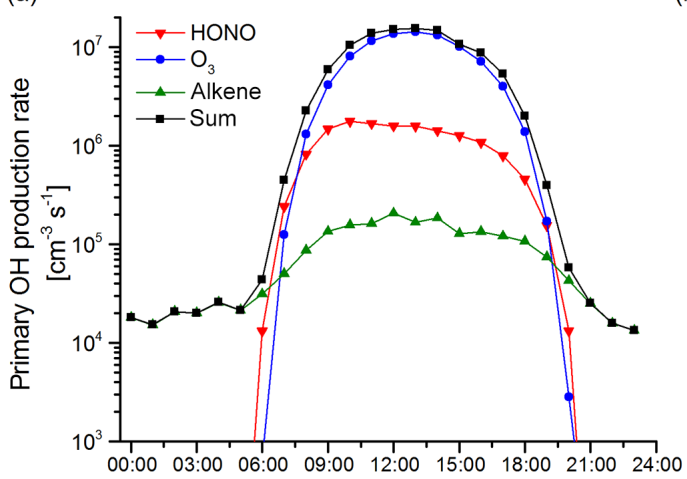

(b)

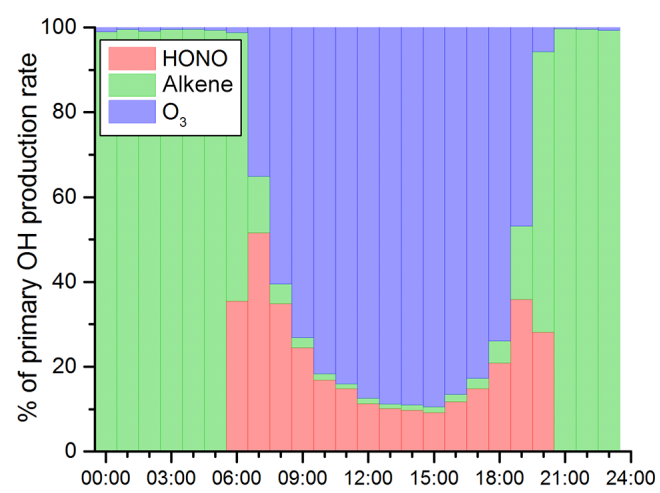

Figure 9. Average diel pattern of primary $\mathrm{OH}$ production from $\mathrm{HONO}, \mathrm{O}_{3}$ and $\mathrm{VOC}$, shown as (a) production rate and (b) percentage contributions to primary $\mathrm{OH}$ production. 
ratio and low correlation between $\mathrm{HONO}$ and $\mathrm{NO}_{2}$ indicate a local source which is independent of $\mathrm{NO}_{2}$. Heterogeneous reactions of $\mathrm{NO}_{2}$ on aerosols play an insignificant role during daytime. Emission from soil, caused either by photolysis of nitrate or gas-soil partitioning of accumulated nitrite/nitrous acid, is supposed to have a higher impact on the HONO concentration during this campaign. Also the NO budget analysis showed a missing source in the humid period, which correlates well with the unknown source of HONO, indicating a common source. The most likely source of HONO and NO is the emission from soil.

Even though the HONO concentration is only in the lower pptv level, it has a high contribution to the primary $\mathrm{OH}$ production in the early morning and evening hours.

\section{Data availability}

Readers who are interested in the data should contact the authors: Hang Su (h.su@mpic.de) or Hannah Meusel (hannah.meusel@mpic.de).

\section{The Supplement related to this article is available online at doi:10.5194/acp-16-14475-2016-supplement.}

Acknowledgements. This study was supported by the Max Planck Society (MPG) and the DFG Research Center/Cluster of Excellence "The Ocean in the Earth System-MARUM".

We thank the Cyprus Institute and the Department of Labor Inspection for the logistical support, as well as the military staff at the Lara Naval Observatory in Ineia for the excellent collaboration.

Furthermore we would like to thank Mathias Soergel for his technical support on experimental setup of atmospheric HONO measurements.

The article processing charges for this open-access publication were covered by the Max Planck Society.

Edited by: N. Mihalopoulos

Reviewed by: two anonymous referees

\section{References}

Acker, K., Moller, D., Auel, R., Wieprecht, W., and Kalass, D.: Concentrations of nitrous acid, nitric acid, nitrite and nitrate in the gas and aerosol phase at a site in the emission zone during ESCOMPTE 2001 experiment, Atmos. Res., 74, 507-524, 2005.

Acker, K., Moller, D., Wieprecht, W., Meixner, F. X., Bohn, B., Gilge, S., Plass-Dulmer, C., and Berresheim, H.: Strong daytime production of $\mathrm{OH}$ from $\mathrm{HNO}_{2}$ at a rural mountain site, Geophys. Res. Lett., 33, L02809, doi:10.1029/2005g1024643, 2006a.

Acker, K., Febo, A., Trick, S., Perrino, C., Bruno, P., Wiesen, P., Moeller, D., Wieprecht, W., Auel, R., Giusto, M., Geyer, A.,
Platt, U., and Allegrini, I.: Nitrous acid in the urban area of Rome, Atmos. Environ., 40, 3123-3133, 2006 b.

Acker, K., Beysens, D., and Moeller, D.: Nitrite in dew, fog, cloud and rain water: An indicator for heterogeneous processes on surfaces, Atmos. Res., 87, 200-212, 2008.

Alicke, B., Platt, U., and Stutz, J.: Impact of nitrous acid photolysis on the total hydroxyl radical budget during the Limitation of Oxidant Production/Pianura Padana Produzione di Ozono study in Milan, J. Geophys. Res.-Atmos., 107, 8196, doi:10.1029/2000jd000075, 2002.

Alicke, B., Geyer, A., Hofzumahaus, A., Holland, F., Konrad, S., Patz, H. W., Schafer, J., Stutz, J., Volz-Thomas, A., and Platt, U.: $\mathrm{OH}$ formation by HONO photolysis during the BERLIOZ experiment, J. Geophys. Res.-Atmos., 108, 8247, doi:10.1029/2001jd000579, 2003.

Ammann, M., Kalberer, M., Jost, D. T., Tobler, L., Rossler, E., Piguet, D., Gaggeler, H. W., and Baltensperger, U.: Heterogeneous production of nitrous acid on soot in polluted air masses, Nature, 395, 157-160, 1998.

Amoroso, A., Domine, F., Esposito, G., Morin, S., Savarino, J., Nardino, M., Montagnoli, M., Bonneville, J. M., Clement, J. C., Ianniello, A., and Beine, H. J.: Microorganisms in Dry Polar Snow Are Involved in the Exchanges of Reactive Nitrogen Species with the Atmosphere, Environ. Sci. Technol., 44, 714719, 2010.

Arens, F., Gutzwiller, L., Baltensperger, U., Gaggeler, H. W., and Ammann, M.: Heterogeneous reaction of $\mathrm{NO}_{2}$ on diesel soot particles, Environ. Sci. Technol., 35, 2191-2199, 2001.

Arey, J., Atkinson, R., and Aschmann, S. M.: Product study of the gas-phase reactions of monoterpenes with the $\mathrm{OH}$ radical in the presence of $\mathrm{NO}_{x}$, J. Geophys. Res.-Atmos., 95, 18539-18546, 1990.

Atkinson, R.: Gas-Phase Tropospheric Chemistry of Volatile Organic Compounds: 1. Alkanes and Alkenes, J. Phys. Chem. Ref. Data, 26, 215-290, 1997.

Atkinson, R., Baulch, D. L., Cox, R. A., Crowley, J. N., Hampson, R. F., Hynes, R. G., Jenkin, M. E., Rossi, M. J., and Troe, J.: Evaluated kinetic and photochemical data for atmospheric chemistry: Volume $\mathrm{I}-$ gas phase reactions of $\mathrm{O}_{x}, \mathrm{HO}_{x}, \mathrm{NO}_{x}$ and $\mathrm{SO}_{x}$ species, Atmos. Chem. Phys., 4, 1461-1738, doi:10.5194/acp-41461-2004, 2004.

Aubin, D. G. and Abbatt, J. P. D.: Interaction of $\mathrm{NO}_{2}$ with hydrocarbon soot: Focus on HONO yield, surface modification, and mechanism, J. Phys. Chem. A, 111, 6263-6273, 2007.

Baergen, A. M. and Donaldson, D. J.: Photochemical Renoxification of Nitric Acid on Real Urban Grime, Environ. Sci. Technol., 47, 815-820, 2013.

Beine, H. J., Allegrini, I., Sparapani, R., Ianniello, A., and Valentini, F.: Three years of springtime trace gas and particle measurements at Ny-Alesund, Svalbard, Atmos. Environ., 35, 36453658, 2001.

Bejan, I., Abd El Aal, Y., Barnes, I., Benter, T., Bohn, B., Wiesen, P., and Kleffmann, J.: The photolysis of ortho-nitrophenols: a new gas phase source of HONO, Phys. Chem. Chem. Phys., 8, 20282035, 2006.

Bianchi, M., Feliatra, F., Tréguer, P., Vincendeau, M.-A., and Morvan, J.: Nitrification rates, ammonium and nitrate distribution in upper layers of the water column and in sediments of the Indian 
sector of the Southern Ocean, Deep-Sea Res. Pt. II, 44, 10171032, 1997.

Bohn, B., Corlett, G. K., Gillmann, M., Sanghavi, S., Stange, G., Tensing, E., Vrekoussis, M., Bloss, W. J., Clapp, L. J., Kortner, M., Dorn, H.-P., Monks, P. S., Platt, U., Plass-Dülmer, C., Mihalopoulos, N., Heard, D. E., Clemitshaw, K. C., Meixner, F. X., Prevot, A. S. H., and Schmitt, R.: Photolysis frequency measurement techniques: results of a comparison within the ACCENT project, Atmos. Chem. Phys., 8, 5373-5391, doi:10.5194/acp-85373-2008, 2008.

Bröske, R., Kleffmann, J., and Wiesen, P.: Heterogeneous conversion of $\mathrm{NO}_{2}$ on secondary organic aerosol surfaces: A possible source of nitrous acid (HONO) in the atmosphere?, Atmos. Chem. Phys., 3, 469-474, doi:10.5194/acp-3-469-2003, 2003.

Costabile, F., Amoroso, A., and Wang, F.: Sub- $\mu$ m particle size distributions in a suburban Mediterranean area. Aerosol populations and their possible relationship with $\mathrm{HONO}$ mixing ratios, Atmos. Environ., 44, 5258-5268, 2010.

Czader, B. H., Rappenglück, B., Percell, P., Byun, D. W., Ngan, F., and Kim, S.: Modeling nitrous acid and its impact on ozone and hydroxyl radical during the Texas Air Quality Study 2006, Atmos. Chem. Phys., 12, 6939-6951, doi:10.5194/acp-12-69392012, 2012.

Donaldson, M. A., Berke, A. E., and Raff, J. D.: Uptake of Gas Phase Nitrous Acid onto Boundary Layer Soil Surfaces, Environ. Sci. Technol., 48, 375-383, 2014a.

Donaldson, M. A., Bish, D. L., and Raff, J. D.: Soil surface acidity plays a determining role in the atmospheric-terrestrial exchange of nitrous acid, P. Natl. Acad. Sci. USA, 111, 18472-18477, 2014b.

Duplissy, J., Gysel, M., Alfarra, M. R., Dommen, J., Metzger, A., Prevot, A. S. H., Weingartner, E., Laaksonen, A., Raatikainen, T., Good, N., Turner, S. F., McFiggans, G., and Baltensperger, U.: Cloud forming potential of secondary organic aerosol under near atmospheric conditions, Geophys. Res. Lett., 35, L03818, doi:10.1029/2007g1031075, 2008.

Elshorbany, Y. F., Steil, B., Brühl, C., and Lelieveld, J.: Impact of HONO on global atmospheric chemistry calculated with an empirical parameterization in the EMAC model, Atmos. Chem. Phys., 12, 9977-10000, doi:10.5194/acp-12-9977-2012, 2012.

Finlayson-Pitts, B. J., Wingen, L. M., Sumner, A. L., Syomin, D., and Ramazan, K. A.: The heterogeneous hydrolysis of $\mathrm{NO}_{2}$ in laboratory systems and in outdoor and indoor atmospheres: An integrated mechanism, Phys. Chem. Chem. Phys., 5, 223-242, 2003.

Foster, J. R., Pribush, R. A., and Carter, B. H.: THE CHEMISTRY OF DEWS AND FROSTS IN INDIANAPOLIS, INDIANA, Atmos. Environ. A-Gen., 24, 2229-2236, 1990.

George, C., Strekowski, R. S., Kleffmann, J., Stemmler, K., and Ammann, M.: Photoenhanced uptake of gaseous $\mathrm{NO}_{2}$ on solidorganic compounds: a photochemical source of HONO?, Faraday Discuss., 130, 195-210, 2005.

Han, C., Liu, Y., and He, H.: Role of Organic Carbon in Heterogeneous Reaction of $\mathrm{NO}_{2}$ with Soot, Environ. Sci. Technol., 47, 3174-3181, 2013.

Harrison, R. M. and Kitto, A. M. N.: Evidence for a surface source of atmospheric nitrous-acid, Atmos. Environ., 28, 1089-1094, 1994.
He, Y., Zhou, X. L., Hou, J., Gao, H. L., and Bertman, S. B.: Importance of dew in controlling the air-surface exchange of HONO in rural forested environments, Geophys. Res. Lett., 33, L02813, doi:10.1029/2005g1024348, 2006.

Heland, J., Kleffmann, J., Kurtenbach, R., and Wiesen, P.: A new instrument to measure gaseous nitrous acid (HONO) in the atmosphere, Environ. Sci. Technol., 35, 3207-3212, 2001.

Hens, K., Novelli, A., Martinez, M., Auld, J., Axinte, R., Bohn, B., Fischer, H., Keronen, P., Kubistin, D., Nölscher, A. C., Oswald, R., Paasonen, P., Petäjä, T., Regelin, E., Sander, R., Sinha, V., Sipilä, M., Taraborrelli, D., Tatum Ernest, C., Williams, J., Lelieveld, J., and Harder, H.: Observation and modelling of $\mathrm{HO}_{x}$ radicals in a boreal forest, Atmos. Chem. Phys., 14, 8723-8747, doi:10.5194/acp-14-8723-2014, 2014.

Hosaynali Beygi, Z., Fischer, H., Harder, H. D., Martinez, M., Sander, R., Williams, J., Brookes, D. M., Monks, P. S., and Lelieveld, J.: Oxidation photochemistry in the Southern Atlantic boundary layer: unexpected deviations of photochemical steady state, Atmos. Chem. Phys., 11, 8497-8513, doi:10.5194/acp-118497-2011, 2011.

Huang, G., Zhou, X. L., Deng, G. H., Qiao, H. C., and Civerolo, K.: Measurements of atmospheric nitrous acid and nitric acid, Atmos. Environ., 36, 2225-2235, 2002.

IUPAC (Ammann, M., Cox, R. A., Crowley, J. N., Jenkin, M. E., Mellouki, A., Rossi, M. J., Troe, J., and Wallington, T. J.): Task Group on Atmospheric Chemical Kinetic Data Evaluation, available at: http://iupac.pole-ether.fr/index.html, last access: June 2015.

Jacobi, H. W., Bales, R. C., Honrath, R. E., Peterson, M. C., Dibb, J. E., Swanson, A. L., and Albert, M. R.: Reactive trace gases measured in the interstitial air of surface snow at Summit, Greenland, Atmos. Environ., 38, 1687-1697, 2004.

Jankowski, J. J., Kieber, D. J., and Mopper, K.: Nitrate and nitrite ultraviolet actinometers, Photochem. Photobiol., 70, 319-328, 1999.

Kalberer, M., Ammann, M., Arens, F., Gaggeler, H. W., and Baltensperger, U.: Heterogeneous formation of nitrous acid (HONO) on soot aerosol particles, J. Geophys. Res.-Atmos., 104, 1382513832, 1999.

Kebede, M. A., Scharko, N. K., Appelt, L. E., and Raff, J. D.: Formation of Nitrous Acid during Ammonia Photooxidation on $\mathrm{TiO}_{2}$ under Atmospherically Relevant Conditions, J. Phys. Chem. Lett., 4, 2618-2623, 2013.

Kerbrat, M., Legrand, M., Preunkert, S., Gallée, H., and Kleffmann, J.: Nitrous acid at Concordia (inland site) and Dumont d'Urville (coastal site), East Antarctica, J. Geophys. Res.-Atmos., 117, D08303, doi:10.1029/2011JD017149, 2012.

Kessler, C. and Platt, U.: Nitrous Acid in Polluted Air Masses - Sources and Formation Pathways, in: Physico-Chemical Behaviour of Atmospheric Pollutants, edited by: Versino, B. and Angeletti, G., Springer, the Netherlands, 412-422, 1984.

Kinugawa, T., Enami, S., Yabushita, A., Kawasaki, M., Hoffmann, M. R., and Colussi, A. J.: Conversion of gaseous nitrogen dioxide to nitrate and nitrite on aqueous surfactants, Phys. Chem. Chem. Phys., 13, 5144-5149, 2011.

Khlystov, A., Stanier, C., and Pandis, S. N.: An algorithm for combining electrical mobility and aerodynamic size distributions data when measuring ambient aerosol, Aerosol Sci. Tech., 38, 229238, 2004. 
Kleanthous, S., Vrekoussis, M., Mihalopoulos, N., Kalabokas, P., and Lelieveld, J.: On the temporal and spatial variation of ozone in Cyprus, Sci. Total Environ., 476-477, 677-687, 2014.

Kleffmann, J. and Wiesen, P.: Heterogeneous conversion of $\mathrm{NO}_{2}$ and $\mathrm{NO}$ on $\mathrm{HNO}_{3}$ treated soot surfaces: atmospheric implications, Atmos. Chem. Phys., 5, 77-83, doi:10.5194/acp-5-772005, 2005.

Kleffmann, J., Becker, K. H., and Wiesen, P.: Heterogeneous $\mathrm{NO}_{2}$ conversion processes on acid surfaces: possible atmospheric implications, Atmos. Environ., 32, 2721-2729, 1998.

Kleffmann, J., Becker, K. H., Lackhoff, M., and Wiesen, P.: Heterogeneous conversion of $\mathrm{NO}_{2}$ on carbonaceous surfaces, Phys. Chem. Chem. Phys., 1, 5443-5450, 1999.

Kleffmann, J., Kurtenbach, R., Lorzer, J., Wiesen, P., Kalthoff, N., Vogel, B., and Vogel, H.: Measured and simulated vertical profiles of nitrous acid - Part I: Field measurements, Atmos. Environ., 37, 2949-2955, 2003.

Kleffmann, J., Gavriloaiei, T., Hofzumahaus, A., Holland, F., Koppmann, R., Rupp, L., Schlosser, E., Siese, M., and Wahner, A.: Daytime formation of nitrous acid: A major source of $\mathrm{OH}$ radicals in a forest, Geophys. Res. Lett., 32, L05818, doi:10.1029/2005g1022524, 2005.

Kleffmann, J., Lörzer, J. C., Wiesen, P., Kern, C., Trick, S., Volkamer, R., Rodenas, M., and Wirtz, K.: Intercomparison of the DOAS and LOPAP techniques for the detection of nitrous acid (HONO), Atmos. Environ., 40, 3640-3652, doi:10.1016/j.atmosenv.2006.03.027, 2006.

Kurtenbach, R., Becker, K. H., Gomes, J. A. G., Kleffmann, J., Lorzer, J. C., Spittler, M., Wiesen, P., Ackermann, R., Geyer, A., and Platt, U.: Investigations of emissions and heterogeneous formation of HONO in a road traffic tunnel, Atmos. Environ., 35, 3385-3394, 2001.

Lammel, G. and Cape, J. N.: Nitrous acid and nitrite in the atmosphere, Chem. Soc. Rev., 25, 361-369, 1996.

Langridge, J. M., Gustafsson, R. J., Griffiths, P. T., Cox, R. A., Lambert, R. M., and Jones, R. L.: Solar driven nitrous acid formation on building material surfaces containing titanium dioxide: A concern for air quality in urban areas?, Atmos. Environ., 43, 51285131, 2009.

Lee, B. H., Wood, E. C., Herndon, S. C., Lefer, B. L., Luke, W. T., Brune, W. H., Nelson, D. D., Zahniser, M. S., and Munger, J. W.: Urban measurements of atmospheric nitrous acid: A caveat on the interpretation of the HONO photostationary state, J. Geophys. Res., 118, 12274-12281, 2013.

Lee, J. D., Whalley, L. K., Heard, D. E., Stone, D., Dunmore, R. E., Hamilton, J. F., Young, D. E., Allan, J. D., Laufs, S., and Kleffmann, J.: Detailed budget analysis of HONO in central London reveals a missing daytime source, Atmos. Chem. Phys., 16, 2747-2764, doi:10.5194/acp-16-2747-2016, 2016.

Legrand, M., Preunkert, S., Frey, M., Bartels-Rausch, Th., Kukui, A., King, M. D., Savarino, J., Kerbrat, M., and Jourdain, B.: Large mixing ratios of atmospheric nitrous acid (HONO) at Concordia (East Antarctic Plateau) in summer: a strong source from surface snow?, Atmos. Chem. Phys., 14, 9963-9976, doi:10.5194/acp-14-9963-2014, 2014.

Lelièvre, S., Bedjanian, Y., Laverdet, G., and Le Bras, G.: Heterogeneous Reaction of $\mathrm{NO}_{2}$ with Hydrocarbon Flame Soot, J. Phys. Chem. A, 108, 10807-10817, 2004.
Levy, H.: Normal Atmosphere: Large Radical and Formaldehyde Concentrations Predicted, Science, 173, 141-143, 1971.

Levy, M., Zhang, R., Zheng, J., Zhang, A. L., Xu, W., GomezHernandez, M., Wang, Y., and Olaguer, E.: Measurements of nitrous acid (HONO) using ion drift-chemical ionization mass spectrometry during the 2009 SHARP field campaign, Atmos. Environ., 94, 231-240, 2014.

Li, J., Reiffs, A., Parchatka, U., and Fischer, H.: In situ measurements of atmospheric $\mathrm{CO}$ and its correlation with $\mathrm{NO}_{x}$ and $\mathrm{O}_{3}$ at a rural mountain site, Meteorol. Meas. Syst., XXII, 25-38, 2015.

Li, S. M.: Equilibrium of particle nitrite with gas-phase HONO tropospheric measurements in the high arctic during sunrise, J. Geophys. Res.-Atmos., 99, 25469-25478, 1994.

Li, X., Brauers, T., Häseler, R., Bohn, B., Fuchs, H., Hofzumahaus, A., Holland, F., Lou, S., Lu, K. D., Rohrer, F., Hu, M., Zeng, L. M., Zhang, Y. H., Garland, R. M., Su, H., Nowak, A., Wiedensohler, A., Takegawa, N., Shao, M., and Wahner, A.: Exploring the atmospheric chemistry of nitrous acid (HONO) at a rural site in Southern China, Atmos. Chem. Phys., 12, 1497-1513, doi:10.5194/acp-12-1497-2012, 2012.

Li, G., Su, H., Li, X., Kuhn, U., Meusel, H., Hoffmann, T., Ammann, M., Pöschl, U., Shao, M., and Cheng, Y.: Uptake of gaseous formaldehyde by soil surfaces: a combination of adsorption/desorption equilibrium and chemical reactions, Atmospheric Chemistry and Physics ,16, 10299-10311, 2016.

Liao, W., Case, A. T., Mastromarino, J., Tan, D., and Dibb, J. E.: Observations of HONO by laser-induced fluorescence at the South Pole during ANTCI 2003, Geophys. Res. Lett., 33, L09810, doi:10.1029/2005GL025470, 2006.

Liu, Y., Han, C., Ma, J., Bao, X., and He, H.: Influence of relative humidity on heterogeneous kinetics of $\mathrm{NO}_{2}$ on kaolin and hematite, Phys. Chem. Chem. Phys., 17, 19424-19431, 2015.

Mamtimin, B., Meixner, F. X., Behrendt, T., Badawy, M., and Wagner, T.: The contribution of soil biogenic NO and HONO emissions from a managed hyperarid ecosystem to the regional $\mathrm{NO}_{x}$ emissions during growing season, Atmos. Chem. Phys., 16, 10175-10194, doi:10.5194/acp-16-10175-2016, 2016.

Mao, J., Ren, X., Chen, S., Brune, W. H., Chen, Z., Martinez, M., Harder, H., Lefer, B., Rappenglück, B., Flynn, J., and Leuchner, M.: Atmospheric oxidation capacity in the summer of Houston 2006: Comparison with summer measurements in other metropolitan studies, Atmos. Environ., 44, 4107-4115, 2010.

Martinez, M., Harder, H., Kubistin, D., Rudolf, M., Bozem, H., Eerdekens, G., Fischer, H., Klüpfel, T., Gurk, C., Königstedt, R., Parchatka, U., Schiller, C. L., Stickler, A., Williams, J., and Lelieveld, J.: Hydroxyl radicals in the tropical troposphere over the Suriname rainforest: airborne measurements, Atmos. Chem. Phys., 10, 3759-3773, doi:10.5194/acp-10-3759-2010, 2010.

Michoud, V., Colomb, A., Borbon, A., Miet, K., Beekmann, M., Camredon, M., Aumont, B., Perrier, S., Zapf, P., Siour, G., AitHelal, W., Afif, C., Kukui, A., Furger, M., Dupont, J. C., Haeffelin, M., and Doussin, J. F.: Study of the unknown HONO daytime source at a European suburban site during the MEGAPOLI summer and winter field campaigns, Atmos. Chem. Phys., 14, 2805-2822, doi:10.5194/acp-14-2805-2014, 2014.

Monge, M. E., D’Anna, B., Mazri, L., Giroir-Fendler, A., Ammann, M., Donaldson, D. J., and George, C.: Light changes the atmospheric reactivity of soot, P. Natl. Acad. Sci. USA, 107, 66056609, 2010. 
Murphy, D. M. and Koop, T.: Review of the vapour pressures of ice and supercooled water for atmospheric applications, Q. J. Roy. Meteor. Soc., 131, 1539-1565, doi:10.1256/qj.04.94, 2005.

Ndour, M., D’Anna, B., George, C., Ka, O., Balkanski, Y., Kleffmann, J., Stemmler, K., and Ammann, M.: Photoenhanced uptake of $\mathrm{NO}_{2}$ on mineral dust: Laboratory experiments and model simulations, Geophys. Res. Lett., 35, 2008.

Novelli, A., Hens, K., Tatum Ernest, C., Kubistin, D., Regelin, E., Elste, T., Plass-Dülmer, C., Martinez, M., Lelieveld, J., and Harder, H.: Characterisation of an inlet pre-injector laserinduced fluorescence instrument for the measurement of atmospheric hydroxyl radicals, Atmos. Meas. Tech., 7, 3413-3430, doi:10.5194/amt-7-3413-2014, 2014.

Oswald, R., Behrendt, T., Ermel, M., Wu, D., Su, H., Cheng, Y., Breuninger, C., Moravek, A., Mougin, E., Delon, C., Loubet, B., Pommerening-Roeser, A., Soergel, M., Poeschl, U., Hoffmann, T., Andreae, M. O., Meixner, F. X., and Trebs, I.: HONO Emissions from Soil Bacteria as a Major Source of Atmospheric Reactive Nitrogen, Science, 341, 1233-1235, 2013.

Oswald, R., Ermel, M., Hens, K., Novelli, A., Ouwersloot, H. G., Paasonen, P., Petäjä, T., Sipilä, M., Keronen, P., Bäck, J., Königstedt, R., Hosaynali Beygi, Z., Fischer, H., Bohn, B., Kubistin, D., Harder, H., Martinez, M., Williams, J., Hoffmann, T., Trebs, I., and Sörgel, M.: A comparison of HONO budgets for two measurement heights at a field station within the boreal forest in Finland, Atmos. Chem. Phys., 15, 799-813, doi:10.5194/acp-15799-2015, 2015.

Paulson, S. E., Chung, M. Y., and Hasson, A. S.: OH radical formation from the gas-phase reaction of ozone with terminal alkenes and the relationship between structure and mechanism, J. Phys. Chem. A, 103, 8125-8138, 1999.

Pikridas, M., Bougiatioti, A., Hildebrandt, L., Engelhart, G. J., Kostenidou, E., Mohr, C., Prévôt, A. S. H., Kouvarakis, G., Zarmpas, P., Burkhart, J. F., Lee, B.-H., Psichoudaki, M., Mihalopoulos, N., Pilinis, C., Stohl, A., Baltensperger, U., Kulmala, M., and Pandis, S. N.: The Finokalia Aerosol Measurement Experiment - 2008 (FAME-08): an overview, Atmos. Chem. Phys., 10, 6793-6806, doi:10.5194/acp-10-6793-2010, 2010.

Pitts, J. N., Sanhueza, E., Atkinson, R., Carter, W. P. L., Winer, A. M., Harris, G. W., and Plum, C. N.: An investigation of the dark formation of nitrous acid in environmental chambers, Int. J. Chem. Kinet., 16, 919-939, 1984.

Ramazan, K. A., Syomin, D., and Finlayson-Pitts, B. J.: The photochemical production of HONO during the heterogeneous hydrolysis of $\mathrm{NO}_{2}$, Phys. Chem. Chem. Phys., 6, 3836-3843, 2004.

Ren, X. R., Harder, H., Martinez, M., Lesher, R. L., Oliger, A., Simpas, J. B., Brune, W. H., Schwab, J. J., Demerjian, K. L., He, Y., Zhou, X. L., and Gao, H. G.: $\mathrm{OH}$ and $\mathrm{HO}_{2}$ chemistry in the urban atmosphere of New York City, Atmos. Environ., 37, 3639-3651, 2003

Ren, X., Brune, W. H., Oliger, A., Metcalf, A. R., Simpas, J. B., Shirley, T., Schwab, J. J., Bai, C., Roychowdhury, U., Li, Y., Cai, C., Demerjian, K. L., He, Y., Zhou, X., Gao, H., and Hou, J.: $\mathrm{OH}, \mathrm{HO}_{2}$, and $\mathrm{OH}$ reactivity during the PMTACSNY Whiteface Mountain 2002 campaign: Observations and model comparison, J. Geophys. Res.-Atmos., 111, D10S03, doi:10.1029/2005jd006126, 2006.

Ren, X., Gao, H., Zhou, X., Crounse, J. D., Wennberg, P. O., Browne, E. C., LaFranchi, B. W., Cohen, R. C., McKay, M.,
Goldstein, A. H., and Mao, J.: Measurement of atmospheric nitrous acid at Bodgett Forest during BEARPEX2007, Atmos. Chem. Phys., 10, 6283-6294, doi:10.5194/acp-10-6283-2010, 2010.

Ren, X., Sanders, J. E., Rajendran, A., Weber, R. J., Goldstein, A. H., Pusede, S. E., Browne, E. C., Min, K.-E., and Cohen, R. C.: A relaxed eddy accumulation system for measuring vertical fluxes of nitrous acid, Atmos. Meas. Tech., 4, 2093-2103, doi:10.5194/amt-4-2093-2011, 2011.

Rubio, M. A., Lissi, E., and Villena, G.: Nitrite in rain and dew in Santiago city, Chile. Its possible impact on the early morning start of the photochemical smog, Atmos. Environ., 36, 293-297, 2002.

Sander, S. P., Abbatt, J., Barker, J. R., Burkholder, J. B., Friedl, R. R., Golden, D. M., Huie, R. E., Kolb, C. E., Kurylo, M. J., Moortgat, G. K., Orkin, V. L., and Wine, P. H.: Chemical Kinetics and Photochemical Data for Use in Atmospheric Studies, Evaluation No. 17, JPL Publication 10-6, Jet Propulsion Laboratory, Pasadena, available at: http://jpldataeval.jpl.nasa.gov (last access: January 2016), 2011.

Scharko, N. K., Berke, A. E., and Raff, J. D.: Release of Nitrous Acid and Nitrogen Dioxide from Nitrate Photolysis in Acidic Aqueous Solutions, Environ. Sci. Technol., 48, 11991-12001, 2014.

Sörgel, M., Regelin, E., Bozem, H., Diesch, J.-M., Drewnick, F., Fischer, H., Harder, H., Held, A., Hosaynali-Beygi, Z., Martinez, M., and Zetzsch, C.: Quantification of the unknown HONO daytime source and its relation to $\mathrm{NO}_{2}$, Atmos. Chem. Phys., 11, 10433-10447, doi:10.5194/acp-11-10433-2011, 2011a.

Sörgel, M., Trebs, I., Serafimovich, A., Moravek, A., Held, A., and Zetzsch, C.: Simultaneous HONO measurements in and above a forest canopy: influence of turbulent exchange on mixing ratio differences, Atmos. Chem. Phys., 11, 841-855, doi:10.5194/acp11-841-2011, 2011b.

Sörgel, M., Trebs, I., Wu, D., and Held, A.: A comparison of measured HONO uptake and release with calculated source strengths in a heterogeneous forest environment, Atmos. Chem. Phys., 15, 9237-9251, doi:10.5194/acp-15-9237-2015, 2015.

Spataro, F., Ianniello, A., Esposito, G., Allegrini, I., Zhu, T., and Hu, M.: Occurrence of atmospheric nitrous acid in the urban area of Beijing (China), Sci. Total Environ., 447, 210-224, 2013.

Stemmler, K., Ammann, M., Donders, C., Kleffmann, J., and George, C.: Photosensitized reduction of nitrogen dioxide on humic acid as a source of nitrous acid, Nature, 440, 195-198, 2006

Stemmler, K., Ndour, M., Elshorbany, Y., Kleffmann, J., D’Anna, B., George, C., Bohn, B., and Ammann, M.: Light induced conversion of nitrogen dioxide into nitrous acid on submicron humic acid aerosol, Atmos. Chem. Phys., 7, 4237-4248, doi:10.5194/acp-7-4237-2007, 2007.

Stutz, J., Alicke, B., and Neftel, A.: Nitrous acid formation in the urban atmosphere: Gradient measurements of $\mathrm{NO}_{2}$ and $\mathrm{HONO}$ over grass in Milan, Italy, J. Geophys. Res.-Atmos., 107, 8192, doi:10.1029/2001jd000390, 2002.

Su, H., Cheng, Y. F., Shao, M., Gao, D. F., Yu, Z. Y., Zeng, L. M., Slanina, J., Zhang, Y. H., and Wiedensohler, A.: Nitrous acid (HONO) and its daytime sources at a rural site during the 2004 PRIDE-PRD experiment in China, J. Geophys. Res.Atmos., 113, D14312, doi:10.1029/2007jd009060, 2008a. 
Su, H., Cheng, Y. F., Cheng, P., Zhang, Y. H., Dong, S., Zeng, L. M., Wang, X., Slanina, J., Shao, M., and Wiedensohler, A.: Observation of nighttime nitrous acid (HONO) formation at a nonurban site during PRIDE-PRD2004 in China, Atmos. Environ., 42, 6219-6232, 2008b.

Su, H., Cheng, Y., Oswald, R., Behrendt, T., Trebs, I., Meixner, F. X., Andreae, M. O., Cheng, P., Zhang, Y., and Poeschl, U.: Soil Nitrite as a Source of Atmospheric HONO and OH Radicals, Science, 333, 1616-1618, 2011.

Tang, Y., An, J., Wang, F., Li, Y., Qu, Y., Chen, Y., and Lin, J.: Impacts of an unknown daytime HONO source on the mixing ratio and budget of HONO, and hydroxyl, hydroperoxyl, and organic peroxy radicals, in the coastal regions of China, Atmos. Chem. Phys., 15, 9381-9398, doi:10.5194/acp-15-9381-2015, 2015.

VandenBoer, T. C., Brown, S. S., Murphy, J. G., Keene, W. C., Young, C. J., Pszenny, A. A. P., Kim, S., Warneke, C., de Gouw, J. A., Maben, J. R., Wagner, N. L., Riedel, T. P., Thornton, J. A., Wolfe, D. E., Dubé, W. P., Öztürk, F., Brock, C. A., Grossberg, N., Lefer, B., Lerner, B., Middlebrook, A. M., and Roberts, J. M.: Understanding the role of the ground surface in HONO vertical structure: High resolution vertical profiles during NACHTT-11, J. Geophys. Res.-Atmos., 118, 10155-10171, 2013.

VandenBoer, T. C., Markovic, M. Z., Sanders, J. E., Ren, X., Pusede, S. E., Browne, E. C., Cohen, R. C., Zhang, L., Thomas, J., Brune, W. H., and Murphy, J. G.: Evidence for a nitrous acid (HONO) reservoir at the ground surface in Bakersfield, CA, during CalNex 2010, J. Geophys. Res.-Atmos., 119, 9093-9106, 2014.

VandenBoer, T. C., Young, C. J., Talukdar, R. K., Markovic, M. Z., Brown, S. S., Roberts, J. M., and Murphy, J. G.: Nocturnal loss and daytime source of nitrous acid through reactive uptake and displacement, Nat. Geosci., 8, 55-60, 2015.

Villena, G., Kleffmann, J., Kurtenbach, R., Wiesen, P., Lissi, E., Rubio, M. A., Croxatto, G., and Rappenglueck, B.: Vertical gradients of HONO, $\mathrm{NO}_{x}$ and O-3 in Santiago de Chile, Atmos. Environ., 45, 3867-3873, 2011.

Vogel, B., Vogel, H., Kleffmann, J., and Kurtenbach, R.: Measured and simulated vertical profiles of nitrous acid - Part II. Model simulations and indications for a photolytic source, Atmos. Environ., 37, 2957-2966, 2003.

Wang, L., Wang, W., and Ge, M.: Heterogeneous uptake of $\mathrm{NO}_{2}$ on soils under variable temperature and relative humidity conditions, J. Environ. Sci., 24, 1759-1766, 2012.

Wang, S. H., Ackermann, R., Spicer, C. W., Fast, J. D., Schmeling, M., and Stutz, J.: Atmospheric observations of enhanced $\mathrm{NO}_{2}$-HONO conversion on mineral dust particles, Geophys. Res. Lett., 30, 1595, doi:10.1029/2003gl017014, 2003.

Weber, B., Wu, D., Tamm, A., Ruckteschler, N., RodriguezCaballero, E., Steinkamp, J., Meusel, H., Elbert, W., Behrendt, T., Soergel, M., Cheng, Y., Crutzen, P. J., Su, H., and Pöschl, U.: Biological soil crusts accelerate the nitrogen cycle through large $\mathrm{NO}$ and HONO emissions in drylands, P. Natl. Acad. Sci. USA, 112, 15384-15389, 2015.

Wentzell, J. J. B., Schiller, C. L., and Harris, G. W.: Measurements of HONO during BAQS-Met, Atmos. Chem. Phys., 10, 1228512293, doi:10.5194/acp-10-12285-2010, 2010.

Wong, K. W., Tsai, C., Lefer, B., Haman, C., Grossberg, N., Brune, W. H., Ren, X., Luke, W., and Stutz, J.: Daytime HONO vertical gradients during SHARP 2009 in Houston, TX, Atmos. Chem. Phys., 12, 635-652, doi:10.5194/acp-12-635-2012, 2012.

Wong, K. W., Tsai, C., Lefer, B., Grossberg, N., and Stutz, J.: Modeling of daytime HONO vertical gradients during SHARP 2009, Atmos. Chem. Phys., 13, 3587-3601, doi:10.5194/acp-13-35872013, 2013.

Yabushita, A., Enami, S., Sakamoto, Y., Kawasaki, M., Hoffmann, M. R., and Colussi, A. J.: Anion-Catalyzed Dissolution of $\mathrm{NO}_{2}$ on Aqueous Microdroplets, J. Phys. Chem. A, 113, 4844-4848, 2009.

Yang, Q., Su, H., Li, X., Cheng, Y., Lu, K., Cheng, P., Gu, J., Guo, S., Hu, M., Zeng, L., Zhu, T., and Zhang, Y.: Daytime HONO formation in the suburban area of the megacity Beijing, China, Sci. China Chem., 57, 1032-1042, 2014.

Ye, C., Zhou, X., Pu, D., Stutz, J., Festa, J., Spolaor, M., Tsai, C., Cantrell, C., Mauldin, R. L., Campos, T., Weinheimer, A., Hornbrook, R. S., Apel, E. C., Guenther, A., Kaser, L., Yuan, B., Karl, T., Haggerty, J., Hall, S., Ullmann, K., Smith, J. N., Ortega, J., and Knote, C.: Rapid cycling of reactive nitrogen in the marine boundary layer, Nature, 532, 489-491, 2016.

Young, C. J., Washenfelder, R. A., Roberts, J. M., Mielke, L. H., Osthoff, H. D., Tsai, C., Pikelnaya, O., Stutz, J., Veres, P. R., Cochran, A. K., VandenBoer, T. C., Flynn, J., Grossberg, N., Haman, C. L., Lefer, B., Stark, H., Graus, M., de Gouw, J., Gilman, J. B., Kuster, W. C., and Brown, S. S.: Vertically Resolved Measurements of Nighttime Radical Reservoirs; in Los Angeles and Their Contribution to the Urban Radical Budget, Environ. Sci. Technol., 46, 10965-10973, 2012.

Zhang, N., Zhou, X. L., Shepson, P. B., Gao, H. L., Alaghmand, M., and Stirm, B.: Aircraft measurement of HONO vertical profiles over a forested region, Geophys. Res. Lett., 36, L15820, doi:10.1029/2009g1038999, 2009.

Zhou, X. L., Beine, H. J., Honrath, R. E., Fuentes, J. D., Simpson, W., Shepson, P. B., and Bottenheim, J. W.: Snowpack photochemical production of HONO: a major source of $\mathrm{OH}$ in the Arctic boundary layer in springtime, Geophys. Res. Lett., 28, 4087-4090, 2001.

Zhou, X. L., Civerolo, K., Dai, H. P., Huang, G., Schwab, J., and Demerjian, K.: Summertime nitrous acid chemistry in the atmospheric boundary layer at a rural site in New York State, J. Geophys. Res.-Atmos., 107, 4590, doi:10.1029/2001jd001539, 2002a.

Zhou, X. L., He, Y., Huang, G., Thornberry, T. D., Carroll, M. A., and Bertman, S. B.: Photochemical production of nitrous acid on glass sample manifold surface, Geophys. Res. Lett., 29, 26-126-4, doi:10.1029/2002g1015080, 2002b.

Zhou, X. L., Gao, H. L., He, Y., Huang, G., Bertman, S. B., Civerolo, K., and Schwab, J.: Nitric acid photolysis on surfaces in low- $\mathrm{NO}_{x}$ environments: Significant atmospheric implications, Geophys. Res. Lett., 30, 2217, doi:10.1029/2003g1018620, 2003.

Zhou, X., Huang, G., Civerolo, K., Roychowdhury, U., and Demerjian, K. L.: Summertime observations of HONO, $\mathrm{HCHO}$, and $\mathrm{O}_{3}$ at the summit of Whiteface Mountain, New York, J. Geophys Res.-Atmos., 112, D08311, doi:10.1029/2006jd007256, 2007.

Zhou, X., Zhang, N., TerAvest, M., Tang, D., Hou, J., Bertman, S., Alaghmand, M., Shepson, P. B., Carroll, M. A., Griffith, S., Dusanter, S., and Stevens, P. S.: Nitric acid photolysis on forest canopy surface as a source for tropospheric nitrous acid, Nat. Geosci., 4, 440-443, 2011. 
Zhou, Y., Rosen, E. P., Zhang, H., Rattanavaraha, W., Wang, W., and Kamens, R. M.: $\mathrm{SO}_{2}$ oxidation and nucleation studies at near-atmospheric conditions in outdoor smog chamber, Environ. Chem., 10, 210-220, 2013. 